DOE/ID-10684

Revision 3

Project No. 23339

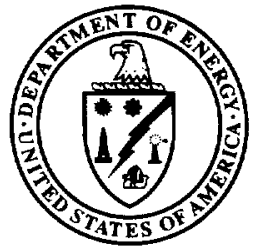

September 2003

U.S. Department of Energy Idaho Operations Office

New Pump and Treat Facility Operations and
Maintenance Plan for Test Area North Final
Groundwater Remediation, Operable Unit 1-07B 
DOE/ID-10684

Revision 3

\section{New Pump and Treat Facility Operations and Maintenance Plan for Test Area North Final Groundwater Remediation, Operable Unit 1-07B}

September 2003 


\section{New Pump and Treat Facility Operations and Maintenance Plan for Test Area North Final Groundwater Remediation, Operable Unit 1-07B}

DOE/ID-10684

Revision 3

September 2003

Approved by

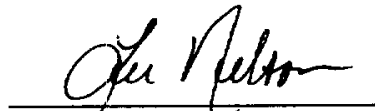

Lee O. Nelson

OU 1-07B Project Manager

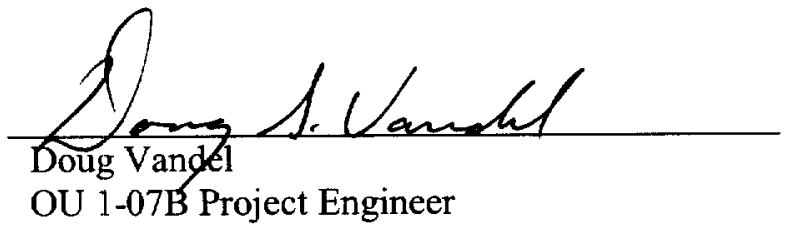

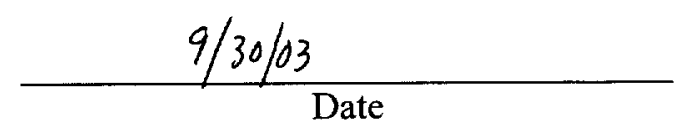

$9 / 30 / 03$ 


\begin{abstract}
This operations and maintenance plan supports the New Pump and Treat Facility (NPTF) remedial action work plan and identifies the approach and requirements for the operations and maintenance activities specific to the final medial zone treatment remedy. The NPTF provides the treatment system necessary to remediate the medial zone portion of the OU 1-07B contaminated groundwater plume. Design and construction of the New Pump and Treat Facility is addressed in the NPTF remedial action work plan. The scope of this operation and maintenance plan includes facility operations and maintenance, remedy five-year reviews, and the final operations and maintenance report for the NPTF.
\end{abstract}




\section{CONTENTS}

1. INTRODUCTION $1-1$

1.1 NPTF Operations \& Maintenance Implementation ................................................ 1-1

1.1.1 Planned NPTF Activities .............................................................

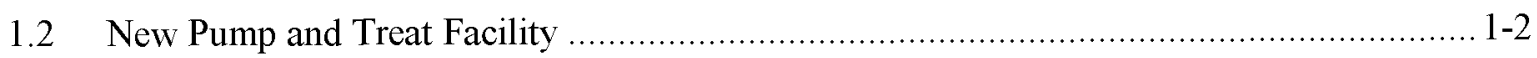

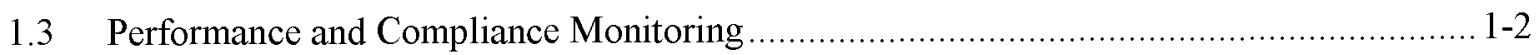

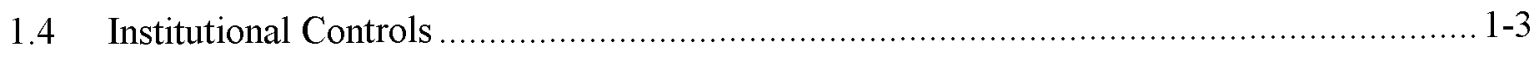

2. TREATMENT FACILITY STARTUP, INSPECTIONS, AND INITIAL CONDITIONS ..........2-1

2.1 Final O\&M Plan and Operations Manual ........................................................... 2-1

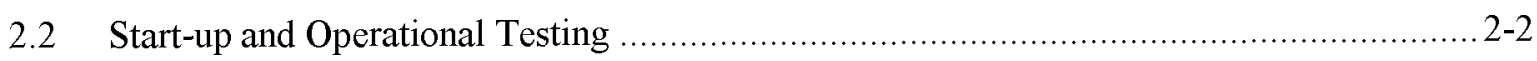

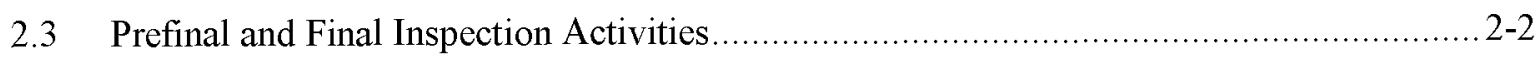

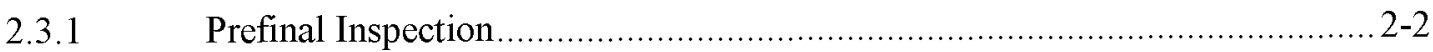

2.3.2 Prefinal Inspection Report .......................................................... 2-2

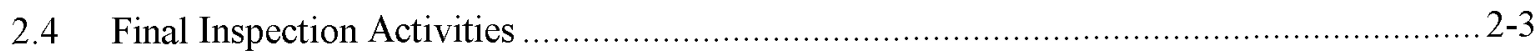

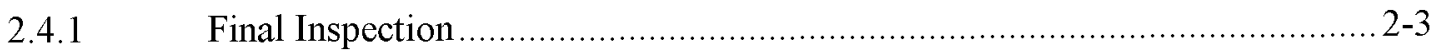

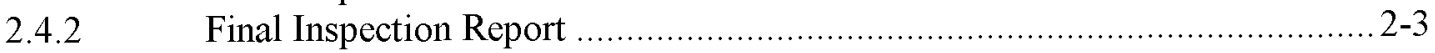

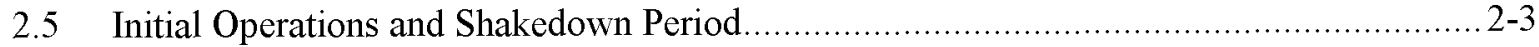

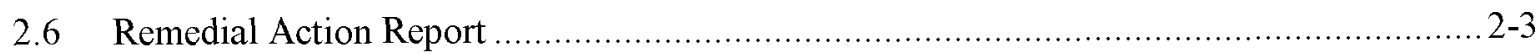

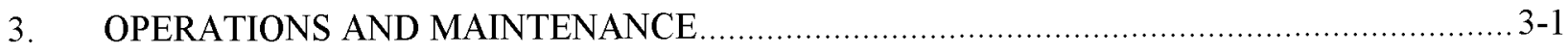

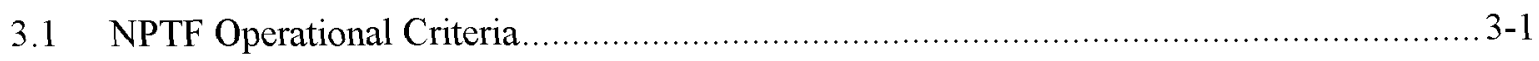

3.1.1 Operational Uptime Requirements ............................................... 3-1

3.1.2 Routine Operations and Maintenance............................................. 3-3

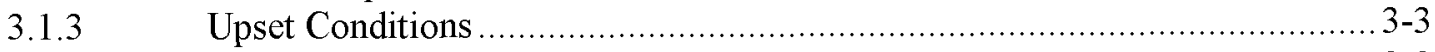

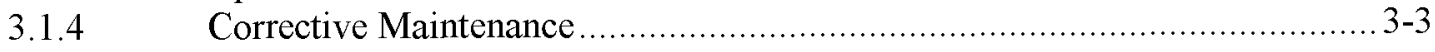

3.2 Operations and Maintenance Procedure Requirements ........................................... 3-3

3.2.1 Personnel Training Program ......................................................... 3-4

3.2.2 Hazard Communication Program Procedure ......................................... 3-4

3.2.3 Daily Routine Procedures ......................................................... 3-4

3.2.4 Treatment Facility Operation Procedures .............................................. 3-4

3.2.5 Infrastructure Operation Procedures.................................................... 3-5

3.2.6 Facility Compliance Monitoring Procedures ….................................. 3-5 
3.2.7 Waste Handling and Tracking Procedures ......................................... 3-5

3.2.8 Eye Wash, Safety Shower, and Other Safety Equipment Procedures ............. 3-5

3.2.9 Emergency Equipment Inspections and Maintenance Procedures .................. 3-5

3.2.10 Emergency Response Procedures ............................................... 3-5

3.2.11 Routine Maintenance Procedures …........................................................ 3-5

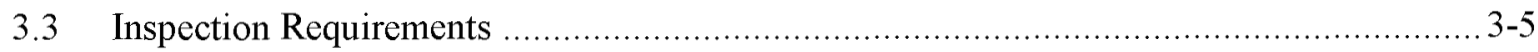

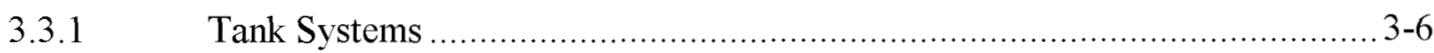

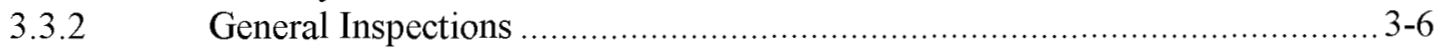

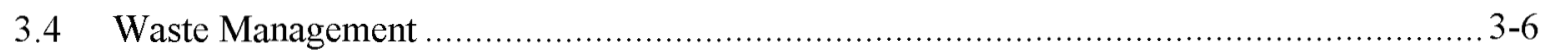

4. REMEDY PERFORMANCE MONITORING ............................................................ $4-1$

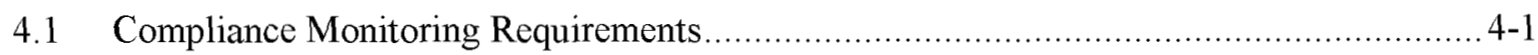

4.1.1 NPTF Compliance Sampling Objectives ......................................... 4-1

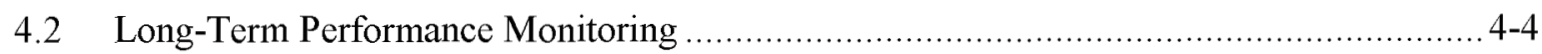

4.2.1 NPTF Capture Zone Performance Monitoring Requirements .................... 4-5

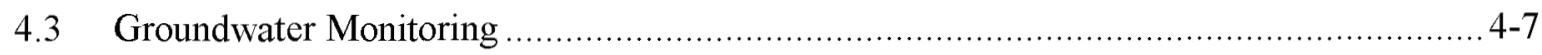

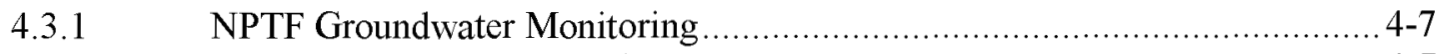

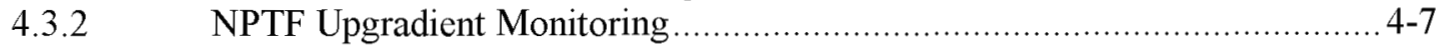

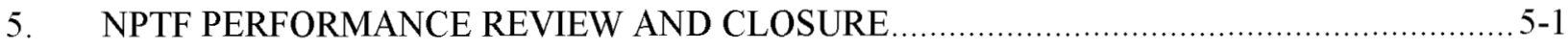

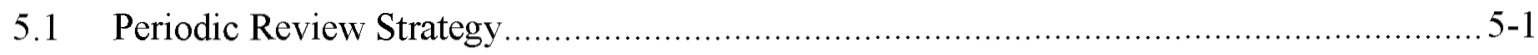

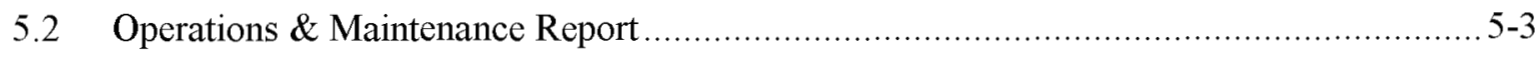

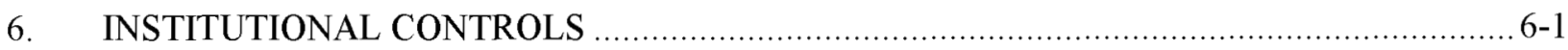

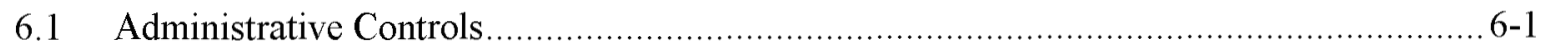

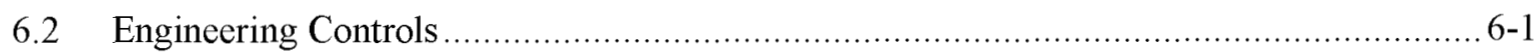

7. DECONTAMINATION AND DECOMMISSIONING ................................................

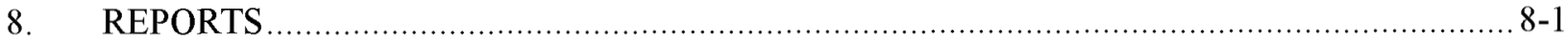

8.1 National Emission Standards for Hazardous Air Pollutants ....................................... 8-1

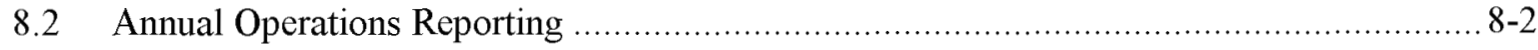

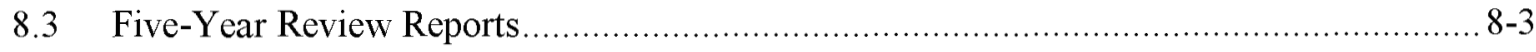

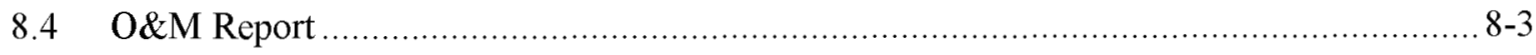




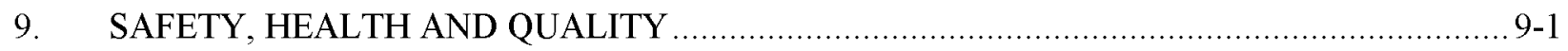

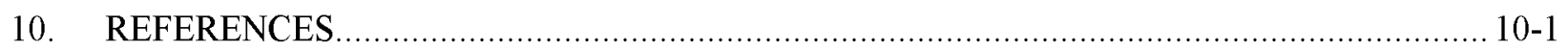

Appendix A -Facility Compliance Monitoring Sampling and Analysis Plan ................................ A-1

Appendix B - NPTF Prefinal Inspection Checklist................................................................. B-1

Appendix C-NPTF Effluent Cumulative Risk Calculation .................................................. C-1

\section{FIGURES}

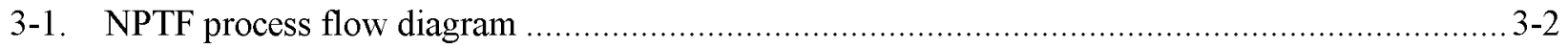

4-1. Well locations for drawdown measurements ........................................................... $4-6$

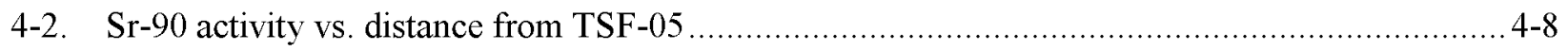

TABLES

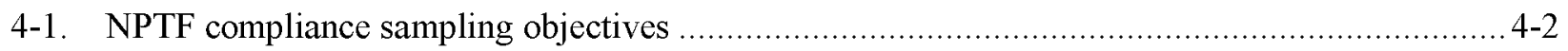

4-2. NPTF Compliance monitoring data management requirements .......................................... 4-3

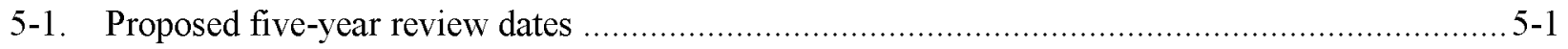




\section{ACRONYMS}

AOC

ARAR

BLM

CERCLA

CFR

$\mathrm{COC}$

CWSA

DCE

DOE

DOE-ID

DOT

EPA

ESD

FFA/CO

GC/MS

HASP

ID

IDEQ

INEEL

ISB

MCL

MCP

MNA

NCP

NLCI area of contamination

applicable or relevant and appropriate requirement

U.S. Bureau of Land Management

Comprehensive Environmental Response, Compensation, and Liability Act

Code of Federal Regulations

contaminant of concern

CERCLA Waste Storage Area

dichloroethene

U.S. Department of Energy

Department of Energy Idaho Operations Office

U.S. Department of Transportation

U.S. Environmental Protection Agency

Explanation of Significant Differences

Federal Facility Agreement and Consent Order

gas chromatography/mass spectrometry

health and safety plan

identification

Idaho Department of Environmental Quality

Idaho National Engineering and Environmental Laboratory

in situ bioremediation

maximum contaminant level

management control procedure

monitored natural attenuation

National Oil and Hazardous Substances Pollution Contingency Plan (40 CFR, Part 300)

no-longer contained-in 


\begin{tabular}{|c|c|}
\hline NPTF & New Pump and Treat Facility \\
\hline O\&M & operations and maintenance \\
\hline OM\&M & operations, monitoring and maintenance \\
\hline $\mathrm{OU}$ & operable unit \\
\hline PCE & tetrachloroethene \\
\hline $\mathrm{QA} / \mathrm{QC}$ & quality assurance/quality control \\
\hline QAPjP & Quality Assurance Project Plan \\
\hline RA & remedial action \\
\hline RAO & remedial action objective \\
\hline RAWP & remedial action work plan \\
\hline $\mathrm{RD} / \mathrm{RA}$ & remedial design/remedial action \\
\hline ROD & Record of Decision \\
\hline SAP & Sampling and Analysis Plan \\
\hline SMO & Sample Management Office \\
\hline SO & system operational \\
\hline SOW & scope of work \\
\hline SP & sampling port \\
\hline TAN & Test Area North \\
\hline TCE & trichloroethene \\
\hline TSF & Technical Support Facility \\
\hline $\mathrm{VC}$ & vinyl chloride \\
\hline VOC & volatile organic compound \\
\hline WAG & waste area group \\
\hline
\end{tabular}




\section{New Pump and Treat Facility Operations and Maintenance Plan for Test Area North Final Groundwater Remediation, Operable Unit 1-07B}

\section{INTRODUCTION}

This operations and maintenance (O\&M) plan is prepared in accordance with the Idaho National Engineering and Environmental Laboratory (INEEL) Federal Facility Agreement and Consent Order (FFA/CO) (DOE-ID 1991) by the U.S. Department of Energy Idaho Operations Office (DOE-ID). This plan addresses O\&M aspects related to the New Pump and Treat Facility (NPTF), which is the system that will be used for remediation of the medial zone portion of the Operable Unit (OU) 1-07B contamination groundwater plume. The O\&M plan was prepared in support of the New Pump and Treat Facility Remedial Action Work Plan for Test Area North Final Groundwater Remediation, Operable Unit 1-07B (DOE-ID 2003b) and in accordance with the Remedial Design/Remedial Action Scope of Work (DOE-ID 2001b).

This O\&M plan addresses the activities and requirements for the long-term operation and maintenance of the OU 1-07B medial zone remedial action.

\section{$1.1 \quad$ NPTF Operations \& Maintenance Implementation}

As described in the NPTF Remedial Action Work Plan (RAWP) (DOE-ID 2003b), implementation of remedial action for the medial zone was initiated through the design, construction, and operation of the NPTF. As described in the Explanation of Significant Differences (ESD) (INEEL 1997), the construction and operation of the NPTF was considered early implementation of Phase C. The NPTF is in full-scale operation and will be used to remove and treat water from the medial zone and to prevent transport of volatile organic compounds (VOCs) greater than maximum contaminant levels (MCLs) into the distal portion of the plume. Decisions to modify the NPTF will be based on the Agency five-year reviews, which may also be used to support a determination by the Agencies that no further action is required.

\subsubsection{Planned NPTF Activities}

The NPTF construction and operation activities as identified in the NPTF RAWP (DOE-ID 2003b) are listed below. Implementation of the activities listed under Item 1 is addressed in the NPTF RAWP. Implementation of the activities listed under Items 2 through 6 are addressed within this O\&M plan as long-term O\&M activities.

1. New facility construction:
a. Design
b. Construction
c. Startup, system operational testing, and Agency prefinal inspection
d. Initial operations and shakedown
e. Final inspection and remedial action report. 
2. NPTF:
a. Operations and maintenance
b. Compliance inspection
c. Waste management.

3. Remedy performance and compliance monitoring:
a. Compliance monitoring
b. Long-term performance monitoring (remedial action objective performance evaluation- support site conceptual model update).

4. Five-year reviews and O\&M report:
a. Five-year reviews
b. O\&M report.

5. Institutional controls

6. Decontamination and decommissioning.

\subsection{New Pump and Treat Facility}

The NPTF is comprised of the equipment and piping needed to extract water from Wells Test Area North (TAN)-38, TAN-39, and TAN-40; to treat the water through two parallel air stripper treatment trains; and to discharge the effluent water into a downgradient injection well. The system will pump water from a combination of the wells at a minimum nominal flow rate of $454 \mathrm{~L} / \mathrm{min}(120 \mathrm{gpm})$. This water will be treated using the air stripper system to reduce VOCs to below $1 \times 10^{-5}$ cumulative risk levels. The extracted groundwater is considered to contain F001 listed waste. Therefore, all components of the extraction system will meet secondary containment requirements from the Resource Conservation and Recovery Act, 40 Code of Federal Regulations (CFR) 264, Subpart J. After the air stripping process, the water is considered to no longer contain the listed hazardous waste (based on No-Longer-Contained-In [NLCI] criteria set by the Idaho Department of Environmental Quality [IDEQ]) and will be discharged to the reinjection well (TAN-53A) without having to comply with the secondary containment requirements of 40 CFR 264, Subpart J.

\subsection{Performance and Compliance Monitoring}

Compliance monitoring for the NPTF will be performed in accordance with the "Facility Compliance Monitoring Sampling and Analysis Plan" (SAP) found in Appendix A of this O\&M Plan. Performance monitoring will be performed in accordance with the Sampling and Analysis Plan for NPTF Performance Monitoring (INEEL 2001b). Monitoring data will be used to document changes in concentrations of contaminants of concern (COCs) over time, provide information on the contaminant removal rate of the plume, and evaluate attainment of remedial action objectives (RAOs). 


\subsection{Institutional Controls}

Institutional controls will consist of engineering and administrative controls to protect current and future users from health risks associated with groundwater contamination by preventing ingestion of groundwater having concentrations of COCs exceeding MCLs, or having a cumulative carcinogenic risk greater than $1 \times 10^{-4}$. Section 6 of this O\&M plan provides additional details of planned institutional

control activities applicable to the medial zone remedial activities. General site institutional controls will be provided in accordance with the Institutional Control Plan for the Test Area North Waste Area Group (WAG) 1 (INEEL 2000). 


\section{TREATMENT FACILITY STARTUP, INSPECTIONS, AND INITIAL CONDITIONS}

At the completion of construction and prior to full-scale operations, the NPTF went through a series of readiness checks. These tasks included the following:

- $\quad$ Final review of the operations plan, manual and procedures

- $\quad$ Management self-assessment review of the facility

- $\quad$ Startup and operational testing

- $\quad$ Prefinal inspection

- Initial operations and shakedown

- $\quad$ Final inspection and report.

The following sections describe in more detail each of the steps leading up to full-scale operations.

\subsection{Final O\&M Plan and Operations Manual}

One month prior to the Agency prefinal inspection for the NPTF, the draft O\&M plan revision and a treatment facility operations manual were submitted to the Agencies for review. These documents provided detailed operations and maintenance procedures, system information, warranty information, and other information necessary for day-to-day operations and maintenance. The O\&M plan and operation manuals addressed the following topics:

1. Technical Concept Narrative

2. System Operation and Maintenance Manual
a. General Information
b. System Description
c. Theory of Operation
d. Operations
e. Preventive Maintenance
f. Trouble Analysis
g. Emergency Response
h. Corrective Maintenance and Checkout Procedures
i. Special Tools and Test Equipment List
j. Spare Parts List 
k. Vendor Data/Acceptance Tests

1. Warranty Data Information

3. Master Equipment List

4. Training Plan

5. Equipment O\&M and Repair Manuals

6. Equipment Maintenance Schedule.

\subsection{Start-up and Operational Testing}

After construction was complete, checkout component testing was performed on all system components to ensure that the equipment had been properly installed and operated in accordance with the design specifications. The component testing was followed by a system operational (SO) cold test to demonstrate proper operation of the total treatment system. The SO testing was performed in accordance with written test procedures.

Concurrent with the SO test, a management self-assessment was conducted to review all operational systems and functions, and outstanding issues identified during the self assessment were resolved and closed prior to the prefinal inspections to determine the facility's operational readiness. This included a review of procedures, training, and other items necessary to safely operate the system.

\subsection{Prefinal and Final Inspection Activities}

The prefinal inspection report provides a means to document the prefinal inspection performed by the DOE-ID, U.S. Environmental Protection Agency (EPA), and Idaho Department of Environmental Quality (IDEQ) project managers, or their designees, at completion of construction activities for the NPTF.

\subsubsection{Prefinal Inspection}

A prefinal inspection for the NPTF was conducted by the Agency project managers, or their designees, prior to initial operations and shakedown of the treatment system. A prefinal inspection checklist was prepared for use in conducting the inspection and was reviewed and accepted by the Agencies prior to performing the inspection. During the inspection open items were recorded on the checklist and actions required to resolve the open items were identified. At the end of the inspection, the Agencies determined which open items needed to be closed prior to proceeding with system operations to treat contaminated water. The "NPTF Prefinal Inspection Checklist" is attached as Appendix B.

\subsubsection{Prefinal Inspection Report}

The Prefinal inspection checklist was completed and updated to include item completion dates. The checklist was then used in place of a formal prefinal inspection report. The checklist identified the open items from the inspection, the agreed-upon action for closing the open items, and the scheduled closure date for each open item. A planned date for the final inspection was selected and recorded in the prefinal inspection minutes. 


\subsection{Final Inspection Activities}

The Agencies determined a final inspection was needed based on the results of the prefinal inspection.

\subsubsection{Final Inspection}

The final inspection focused on verification that open items from the prefinal inspection had been closed and also focused on satisfactory completion of the initial operations and shakedown period.

\subsubsection{Final Inspection Report}

As defined in the Remedial Design/Remedial Action (RD/RA) Scope of Work (SOW) (DOE-ID 1997), a final inspection report, New Pump and Treat Facility Final Inspection Report (INEEL 2001a), was prepared for the NPTF, which addressed the following:

- $\quad$ Results of the checkout component testing and SO testing

- $\quad$ Results of the final inspection

- Evaluation of the effectiveness in meeting treatment system performance requirements based on the results of the shakedown period

- A completed Inspection Checklist

- Resolution of outstanding items from the prefinal inspection

- Identification of any remaining open items with planned completion dates

- $\quad$ Explanation of any system changes from the remedial design and RAWP

- An O\&M plan update.

\subsection{Initial Operations and Shakedown Period}

A complete system integration test was performed using contaminated groundwater after satisfactory closure of the prefinal inspection open action items. Initial operations followed the testing and included a shakedown period to verify that the treatment system met system performance requirements. The operational shakedown period was used to carefully monitor NPTF treatment system operations to ensure that each system was operating in accordance with the approved specifications, was operational and functional, and was compliant with applicable or relevant and appropriate requirements (ARARs).

The shakedown period for the NPTF was completed, and full-scale operations began October 1, 2001.

\subsection{Remedial Action Report}

As specified in the RD/RA SOW (DOE-ID 1997), a remedial action report was prepared for the NPTF. The remedial action report is a primary document with draft, draft final, and final submittals (DOE-ID 2002a). 
The remedial action report addresses the following information:

- $\quad$ Summary of remedial action components as defined in the RAWP (DOE-ID 2003b)

- $\quad$ Explanation of changes to the remedial design and RAWP (DOE-ID 2003b)

- Summary of the results of operational testing, the shakedown period, and the final inspections

- $\quad$ Evaluation of the effectiveness in meeting treatment system performance requirements

- Documentation of closure of any open action items from the final inspection reports

- Summary of data collected during the remedial action that supports a determination that the remedy is operational and functional

- Certification that the remedy is operational and functional

- Identification of documentation necessary to support deletion of the site from the National Priorities List

- An O\&M plan update, if necessary

- A groundwater monitoring plan update, if necessary

- A deactivation, decontamination, and decommissioning plan, if necessary.

An evaluation period of one year was used for the NPTF. During the year of full-scale operations, the above information was gathered, reviewed, and evaluated in efforts to determine that the NPTF was operational and functional. The RA Report (DOE-ID 2002a) was completed and approved by the Agencies in early FY-2002. 


\section{OPERATIONS AND MAINTENANCE}

This section identifies the O\&M requirements for the OU 1-07B medial zone treatment facility. This includes operational criteria and a brief description of the type of procedures that will be developed to operate and maintain the NPTF.

The NPTF RAWP (DOE-ID 2003b) and Section 2 of this document address the remedial action activities that took place prior to the startup of treatment facility operations, including construction, startup and operational testing, and prefinal inspection. The O\&M requirements in this section apply to activities beginning with full-scale system operations

The NPTF remedial design identified the process system design requirements and system descriptions, an equipment list, and the detailed design drawings and specifications for the treatment facility. The system design requirements for the NPTF remedial design were based on the Functional and Operational Requirements for the New Pump and Treat Facility at Test Area North Operable Unit 1-07B (INEEL 1998b). The criteria for the NPTF system operations are identified in Section 3.1.

In order to remove the listed waste code from the treated water, a "no-longer contained-in" (NLCI) determination was needed from the State of Idaho. The NPTF functional and operational requirements specified for the NLCI determination that the effluent water should be treated for VOC removal until all COCs are below their respective MCLs. However, the actual NLCI determination received from the State of Idaho included the criteria that the effluent water must obtain a cumulative risk value for all VOCs of less than $1 \times 10^{-5}$. As a result, the Record of Decision (ROD) Amendment includes both the MCLs and $1 \times 10^{-5}$ cumulative risk as reinjection requirements (DOE-ID 2001a).

The O\&M of the OU 1-07B medial zone facility will be conducted in accordance with the procedures and plans identified to meet the requirement described in the following sections. These procedures and plans will implement the routine daily facility O\&M requirements mandated by ARARs and the requirements for compliance monitoring as addressed in Section 4.1. Operations will also comply with the OU 1-07B Conduct of Operations Conformance Matrix (LST-235).

\subsection{NPTF Operational Criteria}

Operations of the NPTF are performed in accordance with the operational criteria in the following sections. The NPTF process flow diagram is shown in Figure 3-1.

\subsubsection{Operational Uptime Requirements}

The NPTF was designed with an operational uptime goal of greater than $90 \%$. Measures were taken to eliminate possible single-point failure locations throughout the system because of this uptime goal. Redundant components were added to the system to permit continued operations even when some components are not operational. Examples of redundant components are the three-feed and discharge pumps connected to the air strippers. With the dual process train and multiple groundwater extraction locations, virtually all single-point failure locations have been eliminated. The only single-point failure components remaining in the system are the surge tank, the piping immediately before and after the tank, the programmable logic controller, and the re-injection well. The probability for each of these components failing is very low. As designed, this system is expected to achieve an overall system uptime very close to $100 \%$. The operational uptime calculation will be performed on a monthly basis. After one year of operation and monthly thereafter, the operational uptime will be evaluated using a 12-month rolling average. 


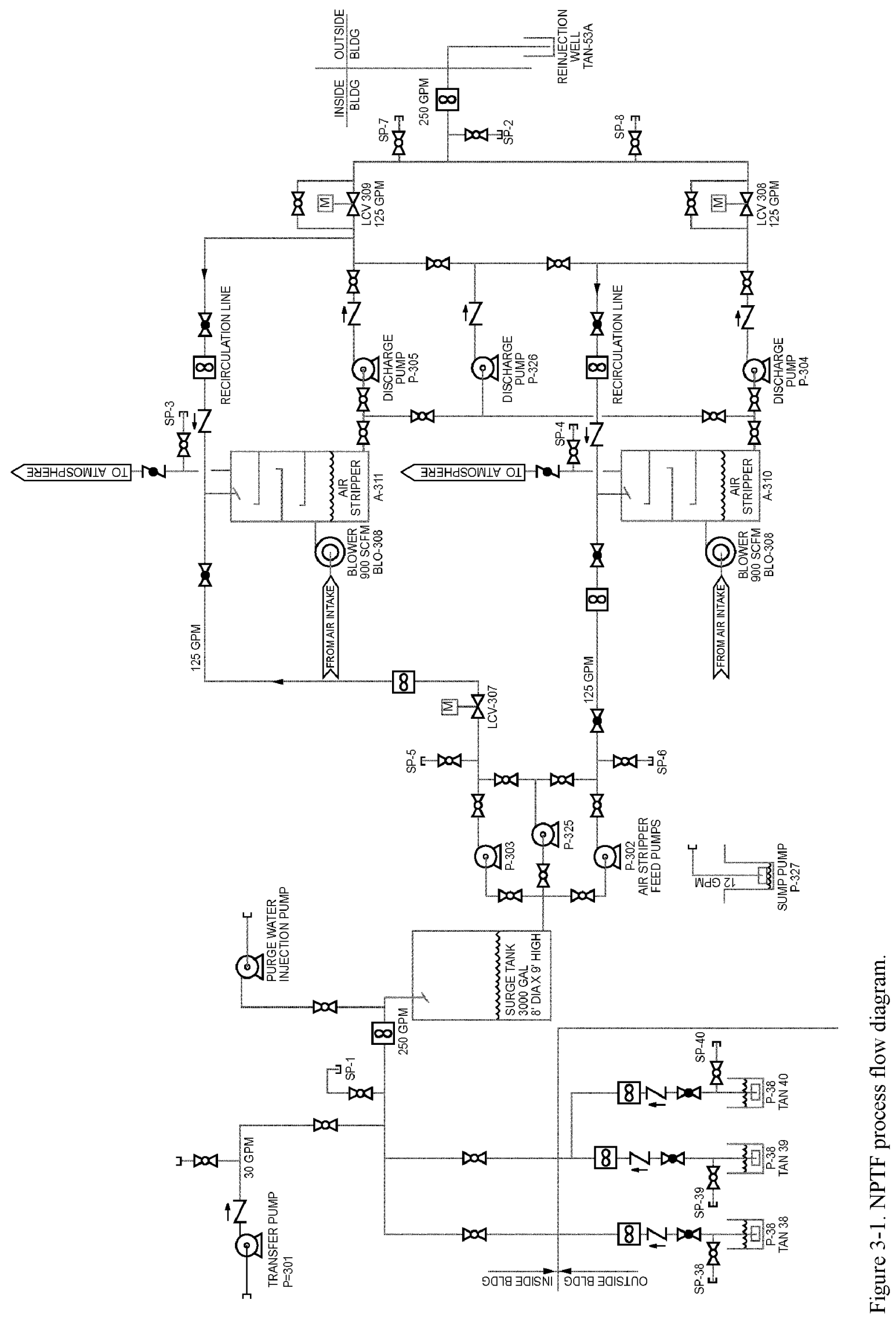


Obtaining the $90 \%$ operational uptime for the NPTF is based on the total operational uptime over a specific period of time. The only expected parameter that may adversely impact this goal is the length of time that the system could be down after a failure occurs. The length of time required to correct any equipment failures should be short enough to ensure that contaminants do not pass through the extraction zone as a result of the natural flow gradient. This maximum length of time is dependent on several different factors, such as the natural flow gradient and the size or extent of the extraction zone.

The extraction zone size can vary greatly depending on the actual pumping scenario (both before and after the downtime). Based on known aquifer characteristics, the length of the extraction zone could range from 30 to $183 \mathrm{~m}$ ( 100 to $600 \mathrm{ft}$ ) long. For a conservative estimate of the maximum allowable downtime, the following parameters can be used: (1) an extraction zone length of $30 \mathrm{~m}(100 \mathrm{ft})$, and (2) a natural gradient flow rate of $0.3 \mathrm{~m} /$ day $(1 \mathrm{ft} /$ day $)$. Assuming that the contaminant only flows through half of the zone while the system is shut down (to ensure that it can be brought back into the pump), the allowable downtime would be 50 days.

For administrative purposes, the maximum NPTF downtime duration will be one week, even though the system could be down for over a month and conservatively ensure that all contaminated groundwater is captured by NPTF operations. An inventory of spare parts is kept on hand at the facility to support any needed corrective maintenance to ensure that the system downtime is minimized.

\subsubsection{Routine Operations and Maintenance}

Operation of the NPTF is performed as described in the NPTF O\&M Manual (INEEL 2002b) and associated procedures.

\subsubsection{Upset Conditions}

During operation of the NPTF, there may be instances where sampling or other information shows the effluent streams exceeding the established discharge limits, or where the effluent streams contain unexpected contaminants. In these situations, the process system will be evaluated immediately and actions identified to correct the problem. If the system is observed to be performing in excess of the permitted discharge limits, the Agencies will be immediately notified and appropriate follow-up action determined. If new components or modifications are needed to address the unexpected contaminants, the situation will be discussed with the Agencies and, with their concurrence, the system may be allowed to continue to operate in its current configuration until the new component or modification can be incorporated.

\subsubsection{Corrective Maintenance}

Corrective maintenance primarily consists of unplanned repairs or replacement of system components after they have failed. Examples could be worn-out pumps, leaky pipes, and electronic equipment. If a failure occurs, the system will be evaluated to determine if there is an alternative operating configuration, what the possible cause is, and what actions should be taken to correct the problem. The proper maintenance activities will then be performed as addressed in the NPTF O\&M Manual (INEEL 2002b).

\subsection{Operations and Maintenance Procedure Requirements}

The requirements outlined in this section pertain specifically to medial zone facility operations. Procedures developed for the treatment system include the following information:

- References to the appropriate work control

- Identification of any potential unique hazards associated with the task procedure 
- Identification of prerequisites to the task procedure

- $\quad$ Procedural steps to accomplish the task

- $\quad$ Post performance activities.

Some procedures reference some activities that are controlled using INEEL site-wide management control procedures (MCPs) or plans that govern specific work tasks. Reference to these procedures is included in the NPTF Operations and Maintenance Manual (INEEL 2002b). The following subsections provide a description of the types of procedure required for remedy operations.

The specific procedures for NPTF were finalized prior to the facility startup and operational testing and are listed in the NPTF O\&M Manual (INEEL 2002b).

\subsubsection{Personnel Training Program}

The objective of this procedural requirement is to describe the personnel training program that is being used for the remedial action. The OU 1-07B training program ensures that all staff are trained to the procedures and plans for tasks/activities that are expected to be performed on a routine or periodic basis.

\subsubsection{Hazard Communication Program Procedure}

The objective of this procedural requirement is to ensure that information concerning the hazards of all chemicals used or handled on this project is known to all affected employees. This information will allow employees to participate in and support the protective measures instituted for this project. This procedure needs to be performed in accordance with the Occupational Safety and Health Act 29 CFR 1910.120.

\subsubsection{Daily Routine Procedures}

The objective of these procedural requirements is to provide project personnel with an outline of routine daily activities at the operating facilities. These activities may include, but are not limited to, the following:

- Housekeeping inspections

- Institutional control inspections

- $\quad$ Comprehensive Environmental Response, Compensation, and Liability Act (CERCLA) Waste Storage Area (CWSA) inspections

- Instrument calibrations

- Inspections on facility equipment and machinery, and routine adjustments

- Inspections of tanks, secondary containment devices, and sumps.

\subsubsection{Treatment Facility Operation Procedures}

The objective of this procedural requirement is to provide the necessary information and direction to properly start up, operate, and shut down the NPTF. These procedures include the operational steps needed to place the system into a normal operating lineup and to place the system in service. These procedures will also include the steps to perform a routine system shutdown. 


\subsubsection{Infrastructure Operation Procedures}

The objective of this procedural requirement is to provide the necessary information and direction to properly operate the treatment facility infrastructure. This information includes startup and shutdown steps, routine maintenance, and system operational checks/settings. These procedures cover utility services such as potable water, electric power, heating and ventilation, and air conditioning.

\subsubsection{Facility Compliance Monitoring Procedures}

The objective of this procedural requirement is to provide necessary information and direction for collecting air and water compliance samples to meet the compliance monitoring requirements in Section 4.1 of this O\&M Plan.

\subsubsection{Waste Handling and Tracking Procedures}

The objective of this procedural requirement is to ensure that all wastes generated during operation of the OU 1-07B Facility are identified, characterized, containerized, labeled, handled, and stored in a safe manner consistent with the Waste Management Plan for Test Area North Final Groundwater Remediation Operable Unit 1-07B (INEEL 2002c) and all applicable requirements. Following these procedures will ensure that the waste containers are periodically inspected, their locations periodically confirmed, and the waste and inspection records maintained. These procedures may also include the requirements for establishing and managing a satellite accumulation area in accordance with the applicable rules and regulations if one is needed.

\subsubsection{Eye Wash, Safety Shower, and Other Safety Equipment Procedures}

The objective of this procedural requirement is to provide general instructions for the use and maintenance of safety equipment used within the OU 1-07B Facility.

\subsubsection{Emergency Equipment Inspections and Maintenance Procedures}

The objective of this procedural requirement is to provide the instructions for the inspection and maintenance of portable fire extinguishers, emergency lights, tank alarms, and other protection systems.

\subsubsection{Emergency Response Procedures}

The objective of this procedural requirement is to describe the steps to be taken when an emergency indicator is triggered or an abnormal condition occurs. These procedures include the operational steps to check for the cause of a leak, to isolate it, and if necessary, to shut down the system so that no influent or effluent may be discharged from within the containment system.

\subsubsection{Routine Maintenance Procedures}

The objective of this procedural requirement is to describe the steps to be taken to provide routine maintenance for various components and equipment associated with the OU 1-07B Facility. Routine activities may include filter change-outs, lubrication, instrument calibration, and freeze protection.

\subsection{Inspection Requirements}

This section describes inspections that are either required by regulations or are considered good management practices. 


\subsubsection{Tank Systems}

As per the requirements promulgated under the Idaho Administrative Procedures Act 58.01.05.008, the tank system used in processing the remediation waste streams generated during remediation operations will comply with the tank system requirements of 40 CFR 264 Subpart J.

To comply with the inspection requirements, the tank systems will be inspected once per operating day. The inspection will consist of checks for visible leakage, signs of corrosion, and the status of the leak detection systems. Specific inspection requirements are to be included in the "Daily Routine" procedures outlined in Section 3.2.3 of this Plan.

\subsubsection{General Inspections}

Daily observations and inspections will be performed as specified in facility-specific procedures. Facility component specific inspections (tank inspections, fence and posting observations, and site physical conditions) will be performed. Monthly inspections will be performed for support systems such as decontamination equipment, spill kits, eye washes, safety showers, and fire extinguishers. Inspections of nonroutine activities, such as groundwater monitoring sampling or short-term tests, will be completed as indicated in the individual plans controlling those activities. A complete list of the NPTF-specific technical procedures can be found in the NPTF Operations and Maintenance Manual (INEEL 2002b).

\subsection{Waste Management}

The NPTF RAWP (DOE-ID 2003b) addresses the general requirements for all wastes generated during the OU 1-07B remedial action, including waste generated during O\&M. Specific waste management requirements are covered in the Waste Management Plan for Test Area North Final Groundwater Remediation, OU 1-07B (INEEL 2002c). 


\section{REMEDY PERFORMANCE MONITORING}

Performance monitoring is required to ensure that the NPTF will meet all remedial action objectives as specified in the governing ROD (DOE-ID 1995). This section on performance monitoring presents the requirements for facility compliance monitoring, long-term facility performance monitoring, and overall plume restoration performance through routine groundwater monitoring.

The objective of performance monitoring is to generate a data set during the period of active restoration that can be used to assess remedy effectiveness. The data set will be a primary component of periodic reviews conducted to assess remedy effectiveness, which requires that each performance monitoring process be designed to generate data of sufficient quality to assess individual treatment system performance as well as overall progress toward restoration of the plume. The following sections present the details for remedy compliance and performance monitoring.

\subsection{Compliance Monitoring Requirements}

The purpose of this section is to provide requirements for collection and analysis of compliance monitoring samples for NPTF. The collection of facility process samples will ensure that the facility is operating in compliance with treated water effluent and air emissions ARARs. The sections below define the sampling objectives and strategy for collecting data to meet those objectives and demonstrate compliant facility operation. Compliance monitoring, sampling, and analysis will be performed as described in Appendix A, "Facility Compliance Monitoring Sampling and Analysis Plan." Compliance samples will be collected in accordance with the sampling objectives and data needs identified in the following sections. Sampling and analysis plan tables will be added to Appendix A of this O\&M plan in the future through the document change process. Compliance monitoring data will be controlled and managed in accordance with the Data Management Plan for the Idaho National Engineering Laboratory Environmental Restoration Program (INEEL 1995). Upgradient source control monitoring will be handled by the Monitored Natural Attenuation (MNA) Operations, Monitoring, and Maintenance (OM\&M) Plan for Test Area North, Operable Unit (OU) 1-07B (DOE-ID 2003a).

\subsubsection{NPTF Compliance Sampling Objectives}

This section identifies NPTF sampling objectives in terms of data needs, sampling location, sampling frequency, sampling procedures, and data validation required to support compliance monitoring of the treatment facility. Figure 3-1 shows the NPTF process flow diagram and identifies specific sampling port (SP) locations with the process flow. Sampling objectives, sample locations, sample frequency, analytes, analytical methods, and quality assurance/quality control (QA/QC) information for NPTF compliance sampling are provided in Table 4-1. Compliance data validation level and data management requirements are presented in Table 4-2. The cumulative risk calculation for the NPTF effluent water will be calculated using the method and assumptions established in Appendix C, "NPTF Effluent Cumulative Risk Calculation." 


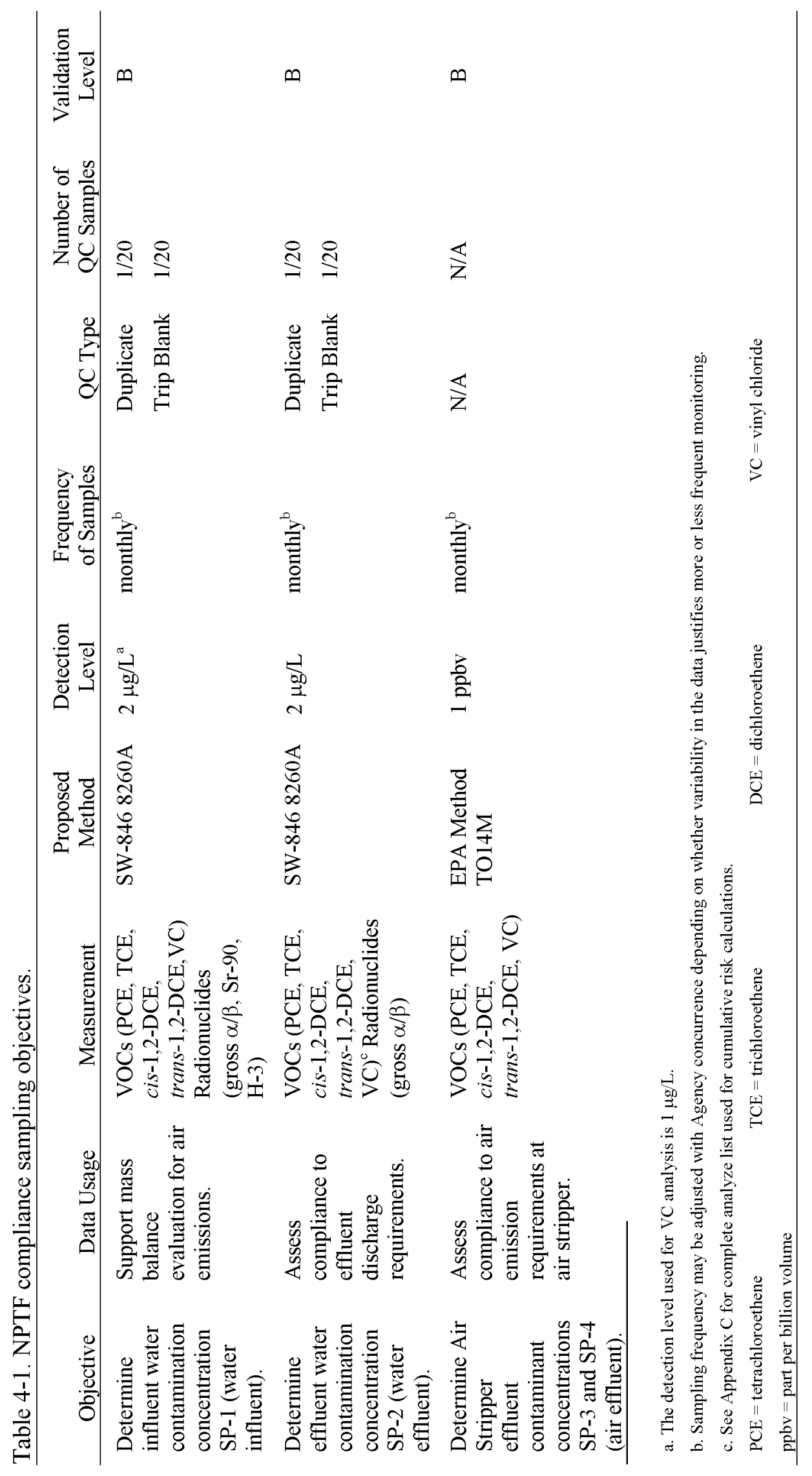


Table 4-2. NPTF Compliance monitoring data management requirements.

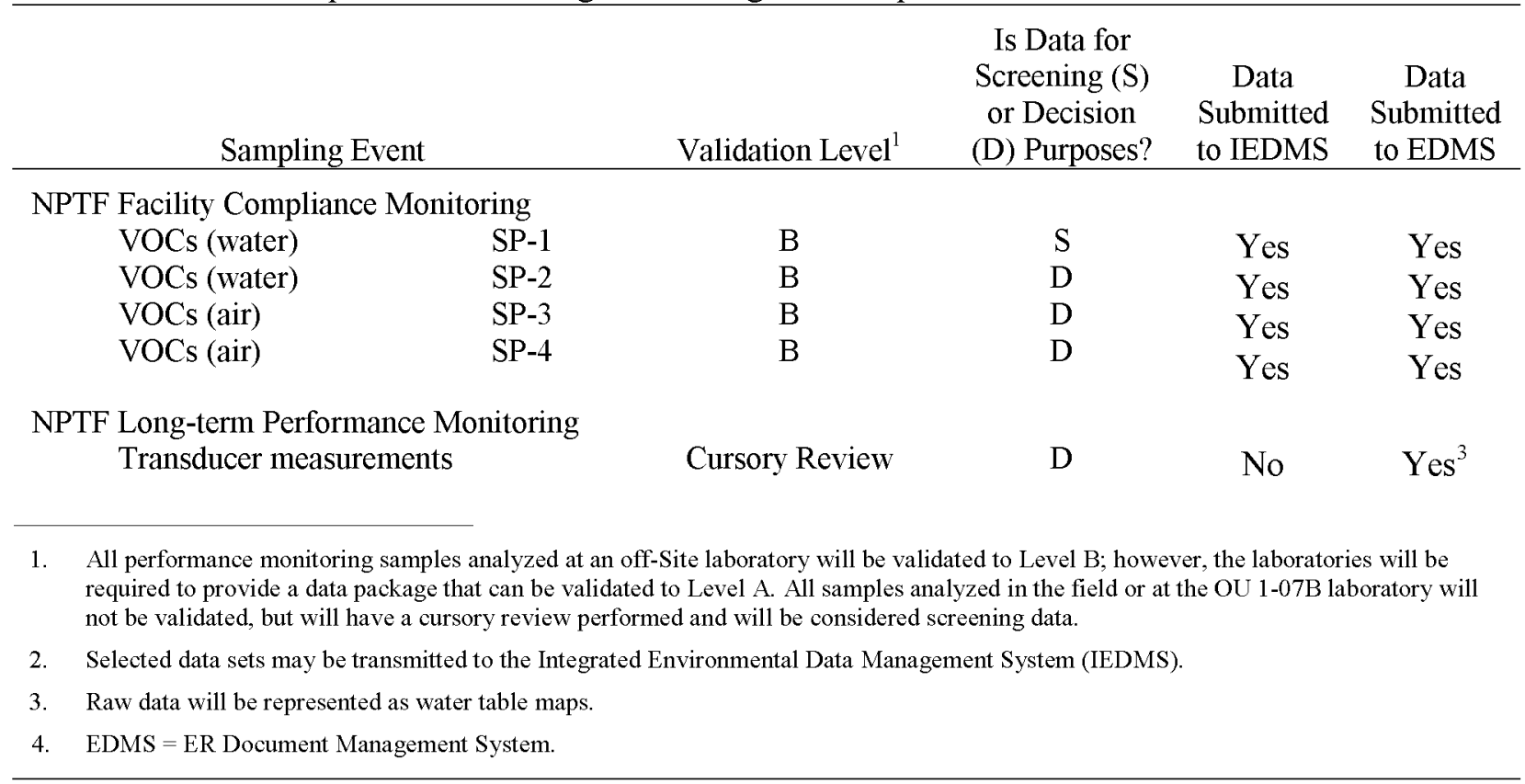

The following sections describe the data needs, sampling location, frequency, equipment, and procedures to be used for NPTF compliance monitoring. Prior to the commencement of sampling activities, all procedural requirements and the project health and safety plan (HASP) (INEEL 2002d) will be reviewed to ensure that the activities will be performed safely and in the prescribed manner. In addition, all supporting documentation will be reviewed to ensure that it is completed correctly and appropriate approval signatures have been obtained, and that the sampling and analysis plan tables have been added to the appropriate sampling and analysis plan (SAP).

4.1.1 Data Needs. To demonstrate compliance with ARARs, it is necessary to obtain quantitative analytical data on effluent samples for comparison with emission control requirements. For the NPTF, the air stripper water effluent must maintain VOC concentrations below the established MCLs, and the air effluent must be maintained below the allowable discharge limits set in the ROD (DOE-ID 1995). Thus, the data needs are for sampling locations, frequencies, and methods to provide analytical results with detection limits and accuracy necessary to determine compliance with stipulated emission criteria. Table 4-1 presents the data quality objectives that meet NPTF data needs. In order to demonstrate compliance with the no-longer-contained-in (NLCI) determination, the NPTF effluent water must be sampled and analyzed for all VOC constituents listed in Appendix C.

In addition, influent water samples will be collected to monitor overall treatment system efficiency. The influent samples will include analysis for VOCs (PCE, TCE, cis-1,2-DCE, trans-1,2-DCE, and VC) and radionuclides $(\mathrm{Sr}-90)$.

4.1.1.2 Sampling Locations. Influent water samples will be collected from SP-1, and effluent water samples will be collected from SP-2. The primary purposes of collecting these samples are: (1) to verify the effectiveness of the treatment system, and (2) to ensure that the effluent meets stipulated emission control requirements. Air samples will be collected from both air strippers at SP-3 (A-311) and SP-4 (A-310). The primary purpose of collecting air samples is to ensure that regulatory air emission concentrations are not exceeded. Figure 3-1, the NPTF process flow diagram, identifies the location of these sampling ports. 
4.1.1.3 Sampling Frequency. During shakedown operations, samples were collected from all four SPs on a daily basis until four consecutive days of sampling results confirmed the NPTF treatment system had met the design effluent requirements. After four consecutive days of successful results, the sampling frequency was reduced to monthly. The sampling frequency may be reevaluated and adjusted periodically as determined and agreed to by the Agencies.

Two considerations need to be addressed when deciding whether sampling frequencies will be changed. First, if data for a specific sample port demonstrate low variability, sampling frequency for that port may be decreased. Conversely, if the data demonstrate high variability, an increase in sampling frequency may be warranted.

Monthly sample results will be used to determine if the extracted water contains any radionuclides. If the extracted water from a given well contains a radionuclide contaminant level that requires processing with water from a downgradient well in order to meet the discharge criteria, then the compliance sampling frequency will be increased to weekly.

4.1.1.4 Equipment and Procedures for Water Influent and Effluent Sampling. Treatment system water influent and effluent sampling will be conducted using the dedicated sampling ports SP-1 and SP-2. Water samples will be collected for VOC and radionuclide analyses as defined in Table 4-1. Sulfuric acid preservatives will be introduced into the VOC sample vials prior to sample collection. The 40-mL VOC analysis vials will be filled completely with no headspace or air bubbles and with water directly from the sample ports. The sample vials will immediately be placed in a cooler with the appropriate amount of blue ice to chill for ensuring successful shipping.

4.1.1.5 Equipment and Procedures for Air Emissions Sampling. NPTF air samples will be collected from air strippers A-311 and A-310 using dedicated sampling ports SP-3 and SP-4, respectively. Samples will be collected in certified clean SUMMA canisters, which have been previously prepared with a waterproof, adhesive sample label. This label will identify the sample port from which the sample will be obtained.

4.1.1.6 Data Validation. Method data validation is the process whereby analytical data are reviewed against set criteria to ensure that the results conform to the requirements of the analytical method and any other specified requirements. All laboratory-generated analytical data supporting compliance monitoring will be validated to Level "B" per GDE-7003, "Levels of Analytical Method Data Validation." To ensure that data of the highest possible quality are received, and to allow flexibility in the case that unforeseen problems are encountered, data packages capable of being validated to Level "A" will be requested from the laboratories.

\subsection{Long-Term Performance Monitoring}

The second component of remedy performance monitoring is the periodic assessment of each treatment system's ability to impact overall plume dynamics as planned. The first objective for treatment facility long-term performance monitoring is to determine whether the original design specifications for hydraulic capture or containment are being maintained. The RAWP set the criteria for the initial assessment of facility performance during SO testing (DOE-ID 2003b). This section defines the requirements for long-term performance monitoring of overall plume restoration achieved by the NPTF.

The second objective for treatment facility long-term performance monitoring is to determine whether downgradient contaminant concentrations are being reduced as a result of treatment system operation. This activity is essentially a component of groundwater monitoring and is incorporated in Section 4.3. The remainder of this section addresses the performance monitoring requirements necessary to assess contaminant capture or containment by each treatment system. 


\subsubsection{NPTF Capture Zone Performance Monitoring Requirements}

The design criterion established for the NPTF to ensure capture of groundwater having TCE concentrations greater than $1,000 \mu \mathrm{g} / \mathrm{L}$ was that the flow rate be sufficient to produce a closed hydraulic head contour at least equal to the width of the $1,000 \mu \mathrm{g} / \mathrm{L} \mathrm{TCE}$ isopleth (INEEL 1998a). Long-term monitoring of NPTF performance with respect to this criterion will consist of the periodic determination of the steady-state drawdown induced by groundwater extraction associated with the facility.

Potentiometric maps generated from drawdown measurements at extraction and observation wells were used to delineate the hydraulic capture zone and estimate its width. Barometric fluctuations of the potentiometric surface can interfere with determining steady state drawdown over an extended period of time. In order to avoid this interference, the drawdown induced by the facility will be determined periodically by shutting down the extraction pumps long enough to allow the water table to recover to ambient conditions, then restarting the facility while measuring drawdown for several hours. The aquifer response to this test should be consistent if it is performed on a regular frequency during the life of the NPTF. If the width of the capture zone is consistent with that observed during system operations testing, the facility performance is adequate. Possible reasons for a change in capture zone geometry include changes in the regional hydrologic conditions or a change in the specific capacity of one or more extraction wells.

4.2.1.1 Data Needs. The ability to measure groundwater capture requires that water levels be measured in the NPTF well field. The necessary water table measurements will occur on two occasions: (1) during ambient conditions with no facility pumping, and (2) during facility pumping when the water table results in a drawdown response. The relative difference in each measurement will be estimated to the nearest $\pm 0.006 \mathrm{~m}( \pm 0.02 \mathrm{ft})$.

4.2.1.2 Water Level Measurement Locations. The well locations at which drawdown measurements will be collected include the following: TAN-19, TAN-32, TAN-34, TAN-36, TAN-38, TAN-39, TAN-40, TAN-41, and TAN-43 (Figure 4-1). Measurement locations may potentially change as alterations to the pumping strategy are made during the life of the NPTF. Any change in selected wells will be based on the ability to acquire water level information that will adequately depict the magnitude and extent of the capture zone.

4.2.1.3 Water Level Measurement Frequency. Drawdown measurements at the selected wells were obtained four times during the first four quarters following NPTF startup. These events were used to confirm that plume capture is measurable and that water level data are reproducible. 


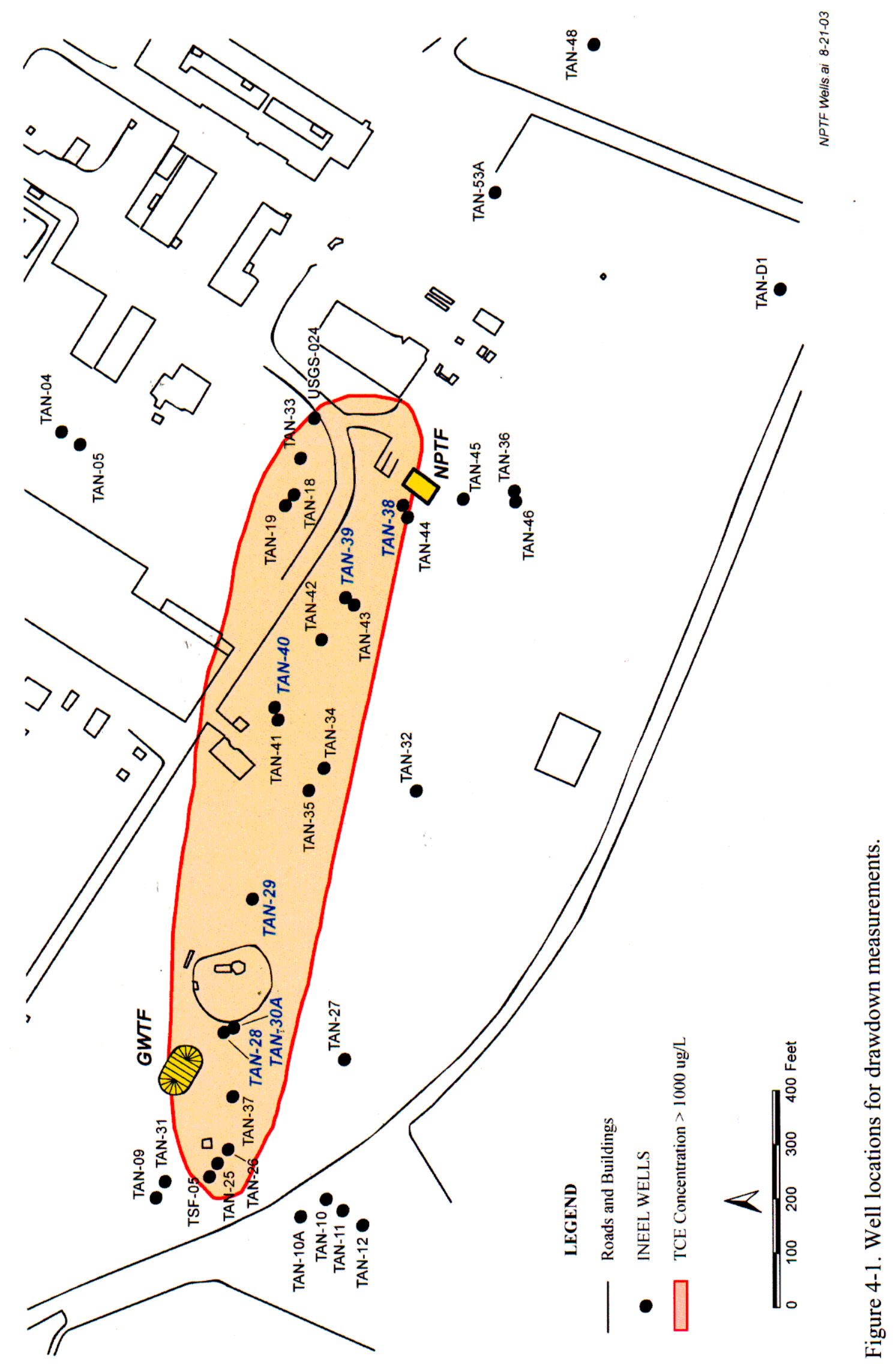


During long-term operations, drawdown measurements will occur once every six months. The change in frequency after the first year is based on data collected during the first year of operation, which show that plume capture is measurable and water level data are reproducible. Furthermore, the decision to decrease the measurement frequency assumes that large-scale changes to aquifer hydraulics and changes to the specific capacity of one or more extraction wells will only be observable over the long term (i.e., > six months).

Two hours prior to each drawdown measurement event, the recording frequency will be increased to once every minute. The NPTF will then be shut down for a period of two hours. After the shutdown period, the NPTF will resume pumping, and measurements will continue to be taken every minute for the remainder of the measuring event. The measurement frequency will then be set back to the normal time period until it is time to perform the next drawdown measuring event.

4.2.1.4 Equipment and Procedures. The equipment used to measure NPTF drawdown includes pressure transducers and data loggers. The transducers used for this application are rated at $10 \mathrm{psi}$ in order to provide the most sensitive water level change data. A transducer is placed approximately $1.5 \mathrm{~m} \mathrm{(5 \textrm {ft } )}$ beneath the surface of the water in each well. Data loggers are used for data collection. Transducers were installed in TAN-38, TAN-39, and TAN-40 as part of the NPTF. Outputs from these transducers are available at the control room of the NPTF.

4.2.1.5 Data Validation. The data collected during each measuring event are considered decision level data because they will be used to evaluate facility effectiveness and to potentially guide regulatory agency-driven decisions. Because the requirement for collected transducer data is only to show relative changes at a given point in time, no validation will be performed on these data. A field check of each pressure transducer will be performed periodically to ensure proper operation. Prior to each NPTF drawdown measurement event, all transducers will be checked for proper operation and calibration. Any transducer found to be functioning outside of the manufacturer's specifications will be replaced prior to beginning the drawdown testing.

\subsection{Groundwater Monitoring}

The purpose of the medial zone groundwater monitoring activities is to obtain data in support of two primary objectives: (1) monitor and evaluate medial zone dynamics in response to NPTF operations and (2) provide data from an upgradient well location for evaluating the possibility of a contaminant slug coming from the hotspot into the medial zone extraction locations. These monitoring activities will be completed in accordance with the SAP for NPTF Performance Monitoring (INEEL 2001b).

\subsubsection{NPTF Groundwater Monitoring}

Vicinity groundwater monitoring will be used to assess remedy effectiveness. Data collected from surrounding groundwater monitoring wells will be used to evaluate treatment effectiveness of the NPTF with the medial zones. TCE concentration tracking from surrounding wells will be evaluated to determine if medial zone cleanup indicators can be identified as a result of NPTF Operations. Data will be collected from wells TAN-33, 36, 43 and 44. These wells were selected because they are in the vicinity of the NPTF, have established baseline concentrations for the contaminants of concern, and can be used for trend evaluations near the NPTF extraction wells.

\subsubsection{NPTF Upgradient Monitoring}

Groundwater monitoring will also be used to track up-gradient radionuclide concentrations, and to determine if a slug of radioactive material is migrating from the hot spot toward the extraction wells of 
the NPTF. Since the NPTF is not currently designed to treat radionuclide-contaminated groundwater, a contingency remedy has been identified to prepare for this possibility. If it is determined that a slug of water begins to travel toward the NPTF that would exceed the treatment capacity of the NPTF, then the Air Stripper Treatment Unit (ASTU) will be activated to contain the advancing slug and to re-inject the radionuclide contaminated water back into the hot-spot area.

In order to evaluate whether a slug of radionuclide-contaminated water is advancing, monitoring data from wells TAN-28, $-30 \mathrm{~A}$, and -29 will be used to evaluate contaminant trends as described in the MNA OM\&M Plan (DOE-ID 2003a). If the trending evaluations indicate that radionuclides are consistently and dramatically increasing, and that the radionuclide concentrations would exceed MCLs at any of the extraction wells, the containment contingency will be invoked. It is important to note that the current Sr-90 levels at wells TAN-37, -28 , and -29 are approximately more than 550,250 , and $20 \mathrm{pCi} / \mathrm{L}$ respectively, while extraction wells TAN-38, -39 , and -40 are all less than $1 \mathrm{pCi} / \mathrm{L}$. This measurement indicates that a marked and sustained increase (at least one order of magnitude) at any of the three monitoring wells must be observed before enacting the contingency remedy.

Based on the regional groundwater flow, it is estimated that it would take 1 to 2 years for groundwater to travel from TAN-29 to the NPTF extraction wells. Additionally, as is shown in Figure 4-2, Sr-90 activity sharply declines as the distance from the secondary source at Technical Support Facility (TSF)-05 increases. Because of the travel time involved, sufficient time should be taken to identify and characterize the slug as sufficiently as possible before implementing the contingency.

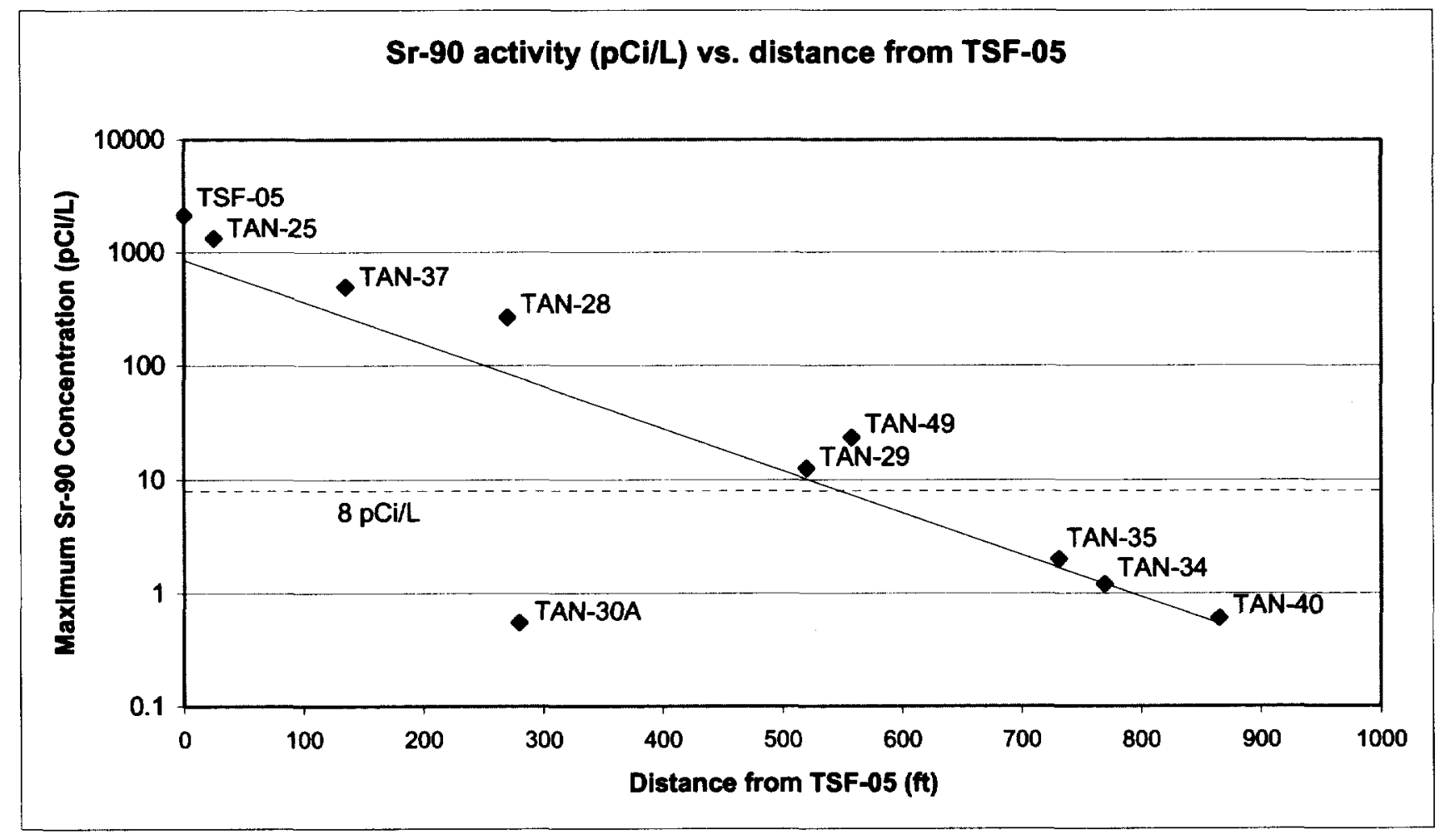

Figure 4-2. Sr-90 activity vs. distance from TSF-05. 


\section{NPTF PERFORMANCE REVIEW AND CLOSURE}

Remedy performance reviews will be conducted in accordance with the National Oil and Hazardous Substances Pollution Contingency Plan (NCP) (40 CFR, Part 300) five-year review process (EPA 1991 and 1994). This section identifies the methods and criteria for measuring performance of the OU 1-07B remedy during the remediation timeframe. In addition, this section also identifies the process and documentation that will be used to determine whether RAOs have been met and that the remedial action is complete. In general, the NCP five-year review process will be used to evaluate the following objectives:

- $\quad$ Identify the process and methods for measuring and evaluating remedy performance.

- $\quad$ Evaluate remedy performance criteria to determine that treatment systems are performing as expected.

- Evaluate performance criteria to determine that RAOs have been achieved and remedial action is complete.

\subsection{Periodic Review Strategy}

The OU 1-07B ROD (DOE-ID 1995) identifies the Agencies' intention of conducting reviews of remedy performance in accordance with the NCP five-year review process (EPA 1991 and 1994). Development of a five-year review strategy is not necessarily directly associated with a single treatment system, but is more of a project-wide concern. The topic is presented herein as a mechanism to begin development of the process, set review timing, and define the scope that will be covered in each five-year review. The details of review timing and subject matter were not presented in the ROD (DOE-ID 1995). However, the EPA has issued guidance for planning and conducting five-year reviews (EPA 1991 and 1994), which may be used to develop the overall strategy for the review process. The first five-year review will be conducted within five years of the start of OU1-07B remedial action (i.e., start of medial zone NPTF operations). Five-year review dates will be set based on when data are expected to be available to adequately conduct a remedy performance review. Table 5-1 identifies proposed review dates for the medial zone remedy based on the commencement date of operations.

Table 5-1. Proposed five-year review dates.

\begin{tabular}{cccc}
$\begin{array}{c}\text { Remedy Component } \\
\text { (Work Element) }\end{array}$ & $\begin{array}{c}\text { Start of Medial } \\
\text { Zone Operations }\end{array}$ & $\begin{array}{c}\text { Time From Start } \\
\text { of Medial Zone } \\
\text { Operations }\end{array}$ & $\begin{array}{c}\text { Proposed } \\
\text { Five-Year } \\
\text { Review Date }\end{array}$ \\
\hline New Pump and Treat Facility & October 2001 & 4 Years & March 2005 \\
\hline
\end{tabular}

The guidance referenced above provides recommendations for the following:

- $\quad$ Purpose of reviews

- $\quad$ Triggering points for conducting and terminating reviews

- $\quad$ Responsibilities, funding, and public participation

- Review content

- Results of reviews. 
The EPA further defines two types of reviews:

1. Statutory Reviews - Conducted in accordance with CERCLA Section 121(c) and NCP Section 300.430(f)(4)(ii) (40 CFR 300) at least every five years or until contaminant levels allow unrestricted use and unlimited exposure

2. Policy Reviews - Conducted as a matter of policy in accordance with Office of Solid Waste and Emergency Response 9355.7-02 (EPA 1991) for remedies selected prior to the enactment of the Superfund Amendments and Reauthorization Act of 1986, or for response actions where, upon completion of the remedial action, no hazardous substances will remain, but five or more years are required to reach that point.

In addition, consideration will be given to the three levels of review addressed in the FFA/CO.

At federal facilities, there are likely to be multiple remedial actions in progress at any given time. As a result, there are three possible levels of review. These levels of review are listed below:

- National Priorities List Site Reviews - Conducted to review the aggregate protectiveness of all remedies in place at the Idaho National Engineering and Environmental Laboratory (INEEL)

- Waste Area Group (WAG) Reviews - Conducted to review the aggregate protectiveness of all remedies in place for each waste area group (e.g., WAG 1)

- Work Element Remedy Reviews - Conducted to review the protectiveness of an individual remedy or component of a remedy (e.g., OU 1-07B NPTF, in situ bioremediation [ISB], and MNA).

In general, the five-year review activities will include the following:

- Review project documents

- $\quad$ Review regulatory standards (ARARs)

- $\quad$ Conduct interviews with project personnel

- Conduct remedy inspection and review technology performance

- Prepare summary report of the review.

The summary report for each five-year review may contain the following:

- $\quad$ Summary of site conditions

- Summary of response action selected

- $\quad$ Summary of response action performed

- Description of post response action activities

- $\quad$ Scope and nature of the five-year review

- Results and recommendations of the five-year review. 
The Agencies will review the guidance provided by the EPA to identify and select the components of a five-year review that will be appropriate for the TAN final groundwater remediation. The results and agreement from the Agency review of EPA guidance will be presented in an OU 1-07B five-year review implementation plan. This consensus document will be prepared to provide direction and guidance for performing and documenting the Agency five-year work element remedy reviews. Evaluation criteria applicable to the NPTF that was identified in the OU 1-07B ROD (DOE-ID 1995) will be considered and discussed during scoping of the five-year review process and will include evaluations to determine from compliance and performance monitoring data whether the medial portion of the groundwater plume is being cleaned up at a rate that supports meeting the RAOs in the expected time duration.

\subsection{Operations \& Maintenance Report}

As addressed in the OU 1-07B RD/RA SOW (DOE-ID 1997), an O\&M report will be prepared and submitted to the Agencies at the completion of the O\&M activities. The O\&M report will be a primary document and will include a draft, draft final, and final submittal. The purpose of the O\&M report will be to provide information that will support an Agency decision that the active remedial action has been successful in supporting the RAOs. This will include information that indicates portions of the contaminated groundwater plume have been reduced to below MCLs and that natural attenuation will cause the remaining portions of the plume to reach MCLs within the 100-year restoration timeframe. Finally, the O\&M report will provide a final deactivation, decontamination, and decommissioning plan for the OU 1-07B treatment facilities. The O\&M report will include the following:

- Description of O\&M activities performed

- $\quad$ Results of remedy performance monitoring

- Summary of the long-term monitoring strategy

- Decontamination and decommissioning plan.

The draft final and final documents will include response to Agency comments. The submittal date for the O\&M report will be established in the appropriate five-year review report. It is anticipated that the submittal date for the NPFT O\&M report will be set in a five-year review report submitted during or before the year 2015 . 


\section{INSTITUTIONAL CONTROLS}

Institutional controls will consist of engineering and administrative controls to protect current and future users from health risks associated with groundwater contamination by preventing ingestion of groundwater having concentrations of COCs exceeding MCLs, or having risk-based concentrations for all contaminants greater than $1 \times 10^{-4}$. This area is considered to be the area of contamination (AOC). Access to the AOC will be institutionally controlled until MCLs, or less than $1 \times 10^{-4}$ risk-based concentrations for all contaminants, are achieved.

The institutional controls for the NPTF will be maintained in accordance with the WAG 1 Institutional Control Plan (INEEL 2000) and will ultimately tie in to an overall site institutional control plan.

\subsection{Administrative Controls}

Administrative controls shall include locking all wells within the project area, requiring project approval before any new wells are constructed, and placing written notification of this remedial action in the facility land use master plan. The notification shall include the following:

- Identify/map the AOC using survey coordinates

- $\quad$ Prohibit installation of any drinking water wells accessing the aquifer within the contaminated plume

- $\quad$ Prohibit engaging in any activities that would interfere with the remedial activity.

A copy of the notification shall be given to the U.S. Bureau of Land Management (BLM), together with a request that a similar notification be placed in the BLM's property management records for this site. The DOE shall provide EPA and the State of Idaho with written verification that notifications, including BLM notification, have been fully implemented. This notification was given concurrent with the startup of the NPTF.

\subsection{Engineering Controls}

Engineering controls shall consist of installing devices to restrict access to the AOC. The devices shall include, but may not be limited to, the following:

- Controlled access to treatment facilities and the CWSA(s)

- Controlled access to well heads

- $\quad$ Signs and postings at treatment facilities and the CWSA(s)

- $\quad$ Postings on well heads identifying potential hazards.

These controls are installed during the construction activities for each facility. 


\section{DECONTAMINATION AND DECOMMISSIONING}

The NPFT RAWP (DOE-ID 2003b) addresses the general requirements for interim decontamination and final deactivation, decontamination, and decommissioning. Specific requirements for interim decontamination are addressed in the Interim Decontamination Plan for Operable Unit 1-07B (INEEL 2002a). Final decontamination and decommissioning of the Phase B Groundwater Treatment Facility will be addressed in a decontamination and decommissioning plan that will be submitted after approval of the RAWP that addresses implementation of the final remedy for the hot spot. Final decontamination and decommissioning of the NPFT remediation facilities will be addressed in a decontamination and decommissioning plan that will be submitted with the O\&M report near the end of the active remediation timeframe. 


\section{REPORTS}

This section provides a summary of the reporting requirements applicable to the operation and maintenance activities for the NPTF. Required reporting includes the annual National Emission Standards for Hazardous Air Pollutants (NESHAPS) reports, the annual operations report, and the O\&M report.

\subsection{National Emission Standards for Hazardous Air Pollutants}

Radionuclide emissions will be included in the INEEL annual National Emission Standards for Hazardous Air Pollutants (NESHAPS) report prepared by INEEL Environmental Monitoring personnel. Emissions will be calculated as provided under the provisions of 40 CFR 61.93 . Data will be provided for input to the INEEL Environmental Systems database from which the National Emission Standards for Hazardous Air Pollutants report is derived.

To estimate the total quantity of radionuclide emissions assumed to be tritium water vapor $\left(T_{\text {tot }}\right)$, process time (t) and air flowrate (da/dt) will be known quantities gathered from NPTF logs, and average tritium concentrations ( $\mathrm{T}_{\text {conc }}$ ) will be known from sampling activities. Various other assumptions are conservatively made at each step of the calculation process.

Mass flowrate $(\mathrm{dm} / \mathrm{dt})$ is calculated with:

$\mathrm{dm} / \mathrm{dt}=(\mathrm{PVM}) /(\mathrm{RT})$

where:

$\mathrm{dm} / \mathrm{dt}=\quad$ mass flowrate $(\mathrm{g} / \mathrm{min})$

$\mathrm{P}=$ Arm pressure $=12.33 \mathrm{psi}=660$ torr

$\mathrm{V}=$ Volumetric flowrate

$\mathrm{R}=62356 \mathrm{~mL}$ torr $/ \mathrm{mol} \mathrm{K}$

$\mathrm{M}=$ Molecular weight of air $=28.96 \mathrm{~g} / \mathrm{mol}$

$\mathrm{T}=$ Air temperature $=$ assumed to be $55^{\circ} \mathrm{F}=12.8^{\circ} \mathrm{C}=286 \mathrm{~K}$.

After calculating mass flowrate in Equation (1), the mass of air discharged $\left(\mathbf{m}_{\text {air }}\right)$ is calculated using:

$\mathrm{m}_{\mathrm{air}}=(\mathrm{dm} / \mathrm{dt}) \mathrm{t}$

where:

$\mathrm{m}_{\mathrm{air}}=$ mass of air discharged ( $\mathrm{g}$ air)

$\mathrm{t}=$ total process time. 
Using the calculated mass of air discharged from Equation (2), the mass of water discharged $\left(\mathrm{m}_{\text {water }}\right)$ can be calculated using:

$\mathrm{m}_{\text {water }}=\mathrm{m}_{\text {air }}\left(\mathrm{W}_{\text {out }}-\mathrm{W}_{\text {in }}\right)$

where:

$\mathrm{m}_{\mathrm{water}}=$ mass of water discharged ( $\mathrm{g}$ water)

$\mathrm{W}_{\text {in }}=$ relative humidity of air entering the system $=$ assumed $0 \%=0 \mathrm{~g}$ water $/ 0 \mathrm{~g}$ dry air

$\mathrm{W}_{\text {out }}=$ relative humidity of air leaving the system $=$ assumed $100 \% @ 55^{\circ} \mathrm{F}\left(12.8^{\circ} \mathrm{C}\right)$

$=0.0092 \mathrm{~g}$ water $/ \mathrm{g}$ dry air (from ASHRAE Psychometric Chart).

Finally, using the calculated mass of water discharged from Equation (3), the total tritium discharged $\left(\mathrm{T}_{\mathrm{tot}}\right)$ can be calculated using:

$\mathrm{T}_{\text {tot }}=\left(\mathrm{m}_{\text {water }}\right)\left(\mathrm{T}_{\text {conc }}\right)(1 \mathrm{~L} / 1000 \mathrm{~g}$ water $)$

where:

$\mathrm{T}_{\mathrm{tot}}=$ total tritium discharged $(\mathrm{pCi})$

$\mathrm{T}_{\text {conc }}=\quad$ average tritium concentration from sampling activities $(\mathrm{pCi} / \mathrm{L})$.

The total quantity of cesium and strontium emitted during NPTF processing will be based on the concentration of cesium and strontium entering the system. It is assumed that $0.1 \%$ of the total cesium and strontium entering the system will be entrained in the NPTF air effluent. The equation that will be used to calculate the total quantity of $\mathrm{Cs}$ and $\mathrm{Sr}$ emitted is:

$\mathrm{R}_{\mathrm{tot}}=\left(\mathrm{m}_{\mathrm{water}}\right)(1 \mathrm{~L} / 1000 \mathrm{~g}$ water $)(0.1 \%)\left(\mathrm{C}_{\mathrm{Cs}}+\mathrm{C}_{\mathrm{Sr}}\right)$

where:

$\mathrm{R}_{\mathrm{tot}}=$ total cesium and strontium discharged $(\mathrm{pCi})$
$\mathrm{C}_{\mathrm{Cs}}=$ average concentration of cesium in the influent water
$\mathrm{C}_{\mathrm{Sr}}=$ average concentration of strontium in the influent water.

\subsection{Annual Operations Reporting}

An NPTF operations report will be prepared and submitted to the Agencies on an annual basis. This report will compile and summarize information contained in the operations logs, daily inspection checklists, water level readings, and maintenance logs. The report will include, but is not limited to, a description of significant events, compliance monitoring results, and the volume of water processed through the system. 


\subsection{Five-Year Review Reports}

Five-year review reports will be prepared and submitted to the Agencies as described in Section 5.1. As further noted in Section 5.1, the content and timing of five-year review reports will be defined in a five-year review implementation plan. These reports will provide information on the effectiveness of the overall plume remediation remedies in obtaining the RAOs. The annual NPTF operations requests will be used for preparation of these reports.

\subsection{O\&M Report}

The O\&M report will be prepared and submitted to the Agencies as described in Section 5.2. This report will document that active remediation has been successful in supporting the RAOs and that NPTF Operations may end. 


\section{SAFETY, HEALTH AND QUALITY}

General safety and health program requirements are addressed in the NPTF RAWP (DOE-ID 2003b). Specific health and safety requirements are covered in the Test Area North Operable Unit 1-07B Final Groundwater Remedial Action Health and Safety Plan (INEEL 2002d). This HASP has been prepared to meet the requirements of the Occupational Safety and Health Act standard, 29 CFR 1910.120/1926.65, "Hazardous Waste Operations and Emergency Response." The HASP governs all work that is performed by employees of the management and operations contractor, subcontractors, or subtier subcontractors to the management and operations contractor, and employees of other companies, or DOE laboratories.

The quality assurance program for this project is controlled by the guidelines outlined in the ER Project Management Plan, PLN-694, and the ER Quality Assurance Project Plan for Waste Area Groups 1, 2, 3, 4, 5, 6, 7, 10, and Inactive Sites (DOE-ID 2002b). 


\section{REFERENCES}

29 CFR 1910.120, 2003, "Hazardous Waste Operations and Emergency Response," Code of Federal Regulations, Office of the Federal Register, April 2003.

29 CFR 1926.65, 2002, "Hazardous Waste Operations and Emergency Response," Code of Federal Regulations, Office of the Federal Register, December 2002.

40 CFR 61.93, 2003, "National Emission Standards for Hazardous Air Pollutants-Emission Monitoring and Test Procedures," Code of Federal Regulations, Office of the Federal Register, July 2003.

40 CFR 264, Subpart J, 2002, "Tank Systems," Code of Federal Regulations, Office of the Federal Register, April 2002.

40 CFR 300, 2003, "National Oil and Hazardous Substances Pollution Contingency Plan," Code of Federal Regulations, Office of the Federal Register, August 2003.

DOE-ID, 1991, Federal Facility Agreement and Consent Order for the Idaho National Engineering Laboratory, Administrative Record No. 1088-06-29-120, U.S. Department of Energy Idaho Operations Office, U.S. Environmental Protection Agency, Region 10, State of Idaho Department of Health and Welfare, December 1991.

DOE-ID, 1995, Record of Decision, Declaration for the Technical Support Facility Injection Well (TSF-05) and Surrounding Groundwater Contamination (TSF-23) and Miscellaneous No Action Sites Final Remedial Action, Operable Unit 1-07B, DOE/ID-10139, U.S. Department of Energy, Idaho Operations Office, August 1995.

DOE-ID, 1997, Remedial Design Remedial Action Scope of Work Test Area North Final Groundwater Remediation Operable Unit 1-07B, DOE/ID-10522, Revision 5, U.S. Department of Energy Idaho Operations Office, August 1997.

DOE-ID, 2001a, Record of Decision Amendment, Technical Support Facility Injection Well (TSF-05) and Surrounding Groundwater Contamination (TSF-23) and Miscellaneous No Action Sites Final Remedial Action, DOE/ID-10139, Revision 0, U.S. Department of Energy Idaho Operations Office, September 2001.

DOE-ID, 2001b, Remedial Design/Remedial Action Scope of Work, DOE/ID-10905, Revision 1, U.S. Department of Energy Idaho Operations Office, November 2001.

DOE-ID, 2002a, New Pump and Treatment Facility Remedial Action Report, Test Area North Final Groundwater Remediation, Operable Unit I-07B, DOE/ID-11031, Revision 0, U.S. Department of Energy Idaho Operations Office, October 2002.

DOE-ID, 2002b, Quality Assurance Project Plan for Waste Area Groups 1, 2, 3, 4, 5, 6, 7, 10 and Inactive Sites, DOE/ID-10587, U.S. Department of Energy Idaho Operations Office, current issue.

DOE-ID, 2003a, Monitored Natural Attenuation Operations, Monitoring, and Maintenance Plan for Test Area North, Operable Unit 1-07B, DOE/ID-11066, Revision 0, U.S. Department of Energy Idaho Operations Office, June 2003. 
DOE-ID, 2003b, New Pump and Treat Facility Remedial Action Work Plan for Test Area North Final Groundwater Remediation, Operable Unit 1-07B, DOE/ID-10679, Revision 1, U.S. Department of Energy Idaho Operations Office, September 2003. (Revision 1 changed the title from Phase $C$ RAWP for TAN Final Groundwater Remediation, OU 1-07B.)

EPA, 1991, Structure and Components of Five-Year Reviews, U.S. Environmental Protection Agency, Office of Solid Waste and Emergency Response, Directive 9355.7-02FS1, August 1991.

EPA, 1994, Supplemental Five-Year Review Guidance, U.S. Environmental Protection Agency, Office of Solid Waste and Emergency Response, Directive 9355.7-02A, August 1994.

GDE-7003, 2002, "Levels of Analytical Method Data Validation," Revision 1, Environmental Restoration, December 2002.

IDAPA 58.01.05.008, 2002, "Standards for Owners and Operators of Hazardous Waste Treatment, Storage, and Disposal Facilities," Idaho Administrative Procedures Act, Idaho Department of Environmental Quality, March 2002.

INEEL, 1995, Data Management Plan for the Idaho National Engineering Laboratory Environmental Restoration Program, INEL-95/0257, Revision 1, Idaho National Engineering and Environmental Laboratory, June 1995.

INEEL, 1997, Explanation of Significant Differences (ESD) from the Record of Decision (ROD) for the Technical Support Facility Injection Well (TSF-05) and Surrounding Groundwater Contamination (TSF-23) and Miscellaneous No Action Sites, Final Remedial Action, Operable Unit 1-07B, Waste Area Group 1, INEEL/EXT-97-00931, Revision 0, Idaho National Engineering and Environmental Laboratory, November 1997.

INEEL, 1998a, Well Characterization and Evaluation Report Supporting Functional and Operational Requirements for the New Pump and Treat Facility at Test Area North Operable Unit 1-07B, INEEL/EXT-97-01356, Revision 0, Idaho National Engineering and Environmental Laboratory, January 1998.

INEEL, 1998b, Functional and Operational Requirements for the New Pump and Treat Facility at Test Area North Operable Unit 1-07B, INEEL/EXT-97-01335, Revision 1, Idaho National Engineering and Environmental Laboratory, September 1998.

INEEL, 2000, Institutional Control Plan for the Test Area North Waste Area Group 1,

INEEL/EXT-2000-00917, Revision 0, Idaho National Engineering and Environmental Laboratory, September 2000.

INEEL, 2001a, New Pump and Treat Facility Final Inspection Report, INEEL/EXT-01-01292, Revision 0, Idaho National Engineering and Environmental Laboratory, September 2001.

INEEL, 2001b, Sampling and Analysis Plan (SAP) for New Pump and Treat Facility (NPTF) Performance Monitoring, TAN OU I-07B, INEEL/EXT-01-01468, Revision 0, Idaho National Engineering and Environmental Laboratory, December 2001.

INEEL, 2002a, Interim Decontamination Plan for Operable Unit 1-07B, INEEL/EXT-97-01287, Revision 4, Idaho National Engineering and Environmental Laboratory, May 2002. 
INEEL, 2002b, New Pump and Treat Facility Operations and Maintenance Manual Volume I, INEEL/EXT-2000-00930, Revision 2, Idaho National Engineering and Environmental Laboratory, July 2002.

INEEL, 2002c, Waste Management Plan for Test Area North Final Groundwater Remediation Operable Unit 1-07B, INEEL/EXT-98-00267, Revision 4, Idaho National Engineering and Environmental Laboratory, September 2002.

INEEL, 2002d, Test Area North Operable Unit 1-07B Final Groundwater Remedial Action Health and Safety Plan, INEEL/EXT-99-00020, Revision 2, Idaho National Engineering and Environmental Laboratory, November 2002.

LST-235, 2003, "Operable Unit 1-07B Conduct of Operations Conformance Matrix (DOE Order 5480.19)," Revision 1, September 2003.

PLN-694, 2003, "Environmental Restoration Project Management Plan," Revision 1, Project and Construction Management, September 2003. 


\section{Appendix A}

Facility Compliance Monitoring

Sampling and Analysis Plan 
A-2 


\section{Appendix A}

\section{Facility Compliance Monitoring Sampling and Analysis Plan A-1 SAMPLING OBJECTIVES}

This section identifies the data needs required for conducting sampling in support of treatment system compliance monitoring. Facility-specific data needs and data quality objectives are defined in Section 3 of the New Pump and Treat Facility Operations and Maintenance Plan for Test Area North Final Groundwater Remediation, Operable Unit 1-07B (DOE-ID 2003a). This Sampling and Analysis Plan (SAP) describes the common features that apply to all performance monitoring activities.

\section{A-1.1 Data Needs}

Data needs have been determined through the evaluation of existing data and the projection of data requirements for confirmation of analytical results obtained during the compliance monitoring process. Data quality objectives, sample locations, sample frequency, analytes, analytical methods, and quality control (QC) information for each treatment facility are identified in Section 3 of the O\&M Plan (DOE-ID 2003a).

\section{A-1.2 Quality Assurance Objectives for Measurement}

The quality assurance (QA) objectives for measurement will meet or surpass the minimum requirements for data quality indicators established in the Quality Assurance Project Plan for Waste Area Groups 1, 2, 3, 4, 5, 6, 7, 10 and Inactive Sites (DOE-ID 2003b), hereinafter referred to as the QAPjP. This reference provides minimum requirements for the following measurement quality indicators: (1) precision, (2) accuracy, (3) representativeness, (4) completeness, and (5) comparability. Precision, accuracy, and completeness will be calculated as per the QAPjP.

\section{A-1.2.1 Precision}

Precision is a measure of the reproducibility of measurements under a given set of conditions. In the field, precision is affected by sample collection procedures and by the natural heterogeneity of the matrix. Overall precision (field and laboratory) can be evaluated by the use of duplicate samples collected in the field. Greater precision is typically required for analytes with very low action levels that are close to background concentrations.

Laboratory precision will be based upon the use of laboratory-generated duplicate samples or matrix spike/matrix spike duplicate samples. Reviews of laboratory precision will be performed during the method data validation process (for Level "A" or "B" validation). Evaluation of laboratory precision projects as it pertains to the overall project data and monitoring controls will be performed during the project's data review.

Field precision will be based upon analysis of collected field duplicates or split samples. For samples collected for laboratory analysis, a field duplicate will be collected at a minimum frequency of $1 / 20$ environmental samples. 


\section{A-1.2.2 Accuracy}

Accuracy is a measure of bias in a measurement system. Laboratory accuracy is demonstrated using laboratory control samples, blind quality control samples, and matrix spikes. Review of laboratory accuracy will be performed during the method data validation process (for Level "A" or "B" validation). Overall accuracy is affected by sample preservation and handling, field contamination, and the sample matrix in the field. False positive or high-biased sample results can be assessed by evaluation of results from field blanks and trip blanks. Evaluation of laboratory and field accuracy effects on the overall data quality will be performed during the project's data review.

Field accuracy will only be determined for samples collected for laboratory analysis. The field accuracy of screening instrumentation used at the task site will be ensured through the use of appropriate calibration procedures and standards.

\section{A-1.2.3 Representativeness}

Representativeness is a qualitative parameter that expresses the degree to which the sampling and analysis data reflect the characteristics being measured. Representativeness will be evaluated by comparing the number of samples collected with the number necessary to be representative, and by confirming that the sample locations were properly determined. For purposes of determining representativeness of the compliance monitoring, samples will be collected from set ports within the facility. Therefore, representativeness assumes that these same sample ports will be used throughout the sampling effort, and changes in sample port selection will have an effect on the parameter that will need to be assessed prior to implementing the change.

\section{A-1.2.4 Detection Limits}

Detection limits will meet or exceed the risk-based or decision-based concentrations for the contaminants of concern. Detection limits will be as specified in the laboratory Master Task Agreement statements of work, task order statements of work, and as described in the QAPjP (DOE-ID 2003b).

\section{A-1.2.5 Completeness}

Completeness is a measure of the quantity of usable data collected during compliance monitoring. The QAPjP requires that an overall completeness goal of $90 \%$ be achieved for noncritical samples. If critical parameters or samples are identified, a $100 \%$ completeness goal is specified. Critical data points are those sample locations or parameters for which valid data must be obtained for the sampling event to be considered complete.

For this project, all laboratory-generated analytical data will be considered critical. The data are required to ensure that the treatment facility is operating properly and that discharges are within the prescribed limits. Therefore, a 100\% completeness goal is required for these data.

\section{A-1.2.6 Comparability}

Comparability is a qualitative characteristic that refers to the confidence with which one data set can be compared to another. At a minimum, comparable data must be obtained using unbiased sampling designs. If sampling designs are not unbiased, the reasons for selecting another design should be well documented. 
For all samples collected for laboratory analyses, comparable laboratory analytical methods will be employed as in previous sampling actions. Therefore, laboratory-generated analytical data will be comparable to that historically obtained. The sample collection ports used are comparable to those previously used at the old facility. However, because this is a new facility, data are not available to which these data can be compared. A database will need to be established before decisions concerning comparability can be formulated.

\section{A-1.3 Data Validation}

Method data validation is the process whereby analytical data are reviewed against set criteria to ensure that the results conform to the requirements of the analytical method and any other specified requirements.

All laboratory-generated analytical data will be validated to Level "B" per INEEL GDE-7003, "Levels of Analytical Method Data Validation." Because compliance monitoring data are just that, monitoring, it is most important to compare newly-generated data to historical to determine whether data conforms to what is predicted. 


\section{A-2 SAMPLING LOCATION AND FREQUENCY}

The material presented in this section is intended to support the data quality objectives summarized in Table 3-1 of the O\&M Plan (DOE-ID 2003a). The Sampling and Analysis Plan (SAP) tables will be generated prior to system operational testing and submitted for approval through a Document Action Request (DAR). The SAP tables will aid in the sample labeling and tracking.

\section{A-2.1 Quality Assurance/Quality Control Samples}

The QA samples will be included to satisfy QA requirements for field operations as per the QAPjP (DOE-ID 2003b). Laboratories approved by the Sample Management Office (SMO) will be used for definitive analyses. The quality assurance/quality control (QA/QC) samples will be collected as outlined in the QAPjP.

\section{A-2.2 Sampling Locations}

Influent and effluent water samples will be collected. The primary purposes of collecting these samples are: (1) to verify the effectiveness of the remedial action, and (2) to ensure that the effluent meets project discharge requirements. Air samples will be collected from air strippers to ensure that regulatory air emission concentrations are not exceeded.

\section{A-2.3 Sampling Frequency}

Samples will be collected from the designated sample ports on a daily basis for the first four days of operation of the new facility. This frequency will then be reduced to monthly sampling. The sampling frequency will be evaluated after the initial six-month period to determine whether adjustments to the schedule need to be made. Another sampling frequency review will be conducted after one year of operations and annually thereafter to determine whether the frequency requires adjustment.

Two considerations need to be addressed when deciding whether sampling frequencies will be changed. First, if data for a specific sampling port demonstrates low variability, sampling frequency for that port may be decreased. Conversely, if the data demonstrates high variability, an increase in sampling frequency may be warranted. 


\section{A-3 SAMPLING DESIGNATION}

A systematic character identification (ID) code will be used to uniquely identify all samples. Uniqueness is required for maintaining consistency and preventing the same ID code from being assigned to more than one sample.

\section{A-3.1 Sampling and Analysis Plan Table}

An SAP table format was developed to simplify the presentation of the sampling scheme for project personnel. The following sections describe the information recorded in the SAP table/database.

\section{A-3.2 Sample Description}

The sample description fields contain information relating individual sample characteristics.

\section{A-3.2.1 Sampling Activity}

The sampling activity field contains the first six characters of the assigned sample number. The sample number in its entirety will be used to link information from other sources (field data, analytical data, etc.) to the information in the SAP table for data reporting, sample tracking, and completeness reporting. The analytical laboratory will also use the sample number to track and report analytical results.

\section{A-3.2.2 Sample Type}

Data in this field will be either "REG" for a regular sample or "QC" for a QC sample.

\section{A-3.2.3 Media}

Data in this field will be "WATER" or "AIR" for all samples.

\section{A-3.2.4 Collection Type}

Data in this field will be "GRAB" for grab samples, "DUP" for duplicate samples, "FBLK" for field blank samples, or "TBLK" for trip blank samples.

\section{A-3.2.5 Planned Date}

This date is related to the planned sample collection start date.

\section{A-3.3 Sample Location Fields}

This group of fields pinpoints the exact location for the sample in three-dimensional space, starting with the general AREA, narrowing the focus to an exact location geographically, then specifying the DEPTH in the depth field.

\section{A-3.3.1 Area}

The AREA field identifies the general sample collection area. This field should contain the standard identifier for the Idaho National Engineering and Environmental Laboratory (INEEL) area being 
sampled. For this compliance monitoring, samples are being collected from Test Area North (TAN). The AREA field identifier will correspond to this site.

\section{A-3.3.2 Location}

This field may contain geographical coordinates, $x-y$ coordinates, building numbers, or other location-identifying details, as well as program-specific information such as a borehole or well number. Data in this field will normally be subordinated to the AREA. This information is included on the labels generated by the Sample Management Office (SMO) to aid sampling personnel. For compliance monitoring, the LOCATION field identifier will correspond to the specific sampling ports (i.e., SP-1, SP-2, SP-3, or SP-4)

\section{A-3.3.3 Type of Location}

The TYPE OF LOCATION field supplies descriptive information concerning the exact sample location. Information in this field may overlap that in the location field, but it is intended to add detail to the location. For compliance monitoring, the TYPE OF LOCATION field will correspond to "INFLUENT," "EFFLUENT," "STRIPPER A-311," or "STRIPPER A-310." These descriptors correspond to sampling ports SP-1, SP-2, SP-3, and SP-4, respectively.

\section{A-3.3.4 Depth}

The DEPTH of a sample location is the distance in feet from surface level or a range in feet from the surface. Because all compliance monitoring samples are being collected from sampling ports located within the New Pump and Treat Facility, the DEPTH field will be marked "N/A."

\section{A-3.4 Analysis Types AT1-AT20}

These fields indicate analysis types (radiological, chemical, hydrological, etc.). Space is provided at the bottom of the form to clearly identify each type. A standard abbreviation should also be provided, if possible. For compliance monitoring, the analysis types will be "VG" (volatile organic compound [VOC] analysis by gas chromatography/mass spectrometry [GC/MS]), "VF" (VOC analysis by GC/MS, matrix spike/matrix spike duplicate), "VT" (VOC analysis by a modified U.S. Environmental Protection Agency [EPA] Method TO-14), and "R5" (gamma screen). 


\section{A-4 SAMPLING EQUIPMENT AND PROCEDURES}

The following sections describe the sampling procedures and equipment to be used for the planned sampling and analyses described for compliance monitoring. Prior to the commencement of any sampling activities, all procedural requirements and the project health and safety plan (HASP) will be reviewed to ensure that the activities will be performed safely and in the prescribed manner. In addition, all supporting documentation will be reviewed to ensure that it is completed correctly and appropriate approval signatures have been obtained.

\section{A-4.1 Influent and Effluent Sampling}

Influent and effluent sampling will be conducted using the dedicated sampling ports. A standard operating procedure describing the sampling operation will be written and approved by the project management team prior to any sampling activities. Water samples will be collected for VOC and radionuclide analyses as defined in Table 4-1 of the NPTF O\&M Plan (DOE-ID 2003a). A water aliquot will be collected to determine the correct amount of preservative and will be tested for $\mathrm{pH}$. Sulfuric acid preservative will be introduced into the sample vials prior to sample collection. The $40-\mathrm{mL}$ volatile organic analysis vials will be filled completely with no headspace or air bubbles. The sample vials will immediately be placed in a cooler with the proper amount of blue ice to ensure adequate chill for the length of shipping time.

\section{A-4.2 Air Emissions Sampling}

Air samples will be collected from the air strippers using dedicated sampling ports. A standard operating procedure describing the sampling operation will be written and approved by the project management team prior to any sampling activities. Samples will be collected in certified clean SUMMA canisters that have been evacuated to 10 torr minimum. The vacuum in the canister simplifies air sample collection. The canisters will be labeled prior to sampling with a waterproof, adhesive sample label. This label will define the sampling port from which the sample will be obtained.

Prior to sampling, the sampler will purge the sampling lines with the air stripper air effluent. When the lines are purged, the inlet valve on the Summa canister will be opened to fill the evacuated canister with an air sample. Once the sample is collected, it will be packaged and shipped to the laboratory for analysis.

\section{A-4.3 Shipping Screening}

Following collection, samples will be surveyed for external contamination and field-screened for radiation levels. For water samples exhibiting field-screening results above background levels, a gamma screening sample will be collected and submitted to the Radiation Measurements Laboratory located at the Test Reactor Area at the INEEL for a 20-minute analysis prior to shipment. The water sample submitted for gamma screening does not require preservation. If radionuclides are detected, the screening results will be included with the sample shipment to alert the laboratory to any radiological hazards. 


\section{A-5 DOCUMENT MANAGEMENT AND SAMPLE CONTROL}

This section summarizes document management and sample control. Documentation includes field logbooks used to record field data and sampling procedures, chain-of-custody forms, and sample container labels. In addition, sample handling is outlined and chain-of-custody, radioactivity screening, and sample packaging for shipment to the analytical laboratories are discussed. The analytical results from the sampling efforts will be documented in the annual report.

\section{A-5.1 Documentation}

The field team leader will be responsible for controlling and maintaining all field documents and records, and for ensuring that all required documents will be submitted to INEEL Environmental Restoration Administrative Records and Document Control. All entries will be made in permanent ink. All errors will be corrected by drawing a single line through the error and entering the correct information. All corrections will be initialed and dated.

\section{A-5.1.1 Sample Container Labels}

Waterproof, gummed labels generated from the SAP database will display information such as the sample ID number, the name of the project, sample location, and analysis type. In the field, labels will be completed and placed on the containers before collecting the sample. Information concerning sample date, time, preservative used, field measurements of hazards, and the sampler's initials will be filled out during field sampling.

\section{A-5.1.2 Field Guidance Forms}

Field guidance forms, provided for each sample location, will be generated from the SAP database to ensure unique sample numbers. Used to facilitate sample container documentation and organization of field activities, these forms contain information regarding the following:

- $\quad$ Media

- $\quad$ Sample ID numbers

- $\quad$ Sample location

- $\quad$ Aliquot ID (as bottle or analysis code)

- $\quad$ Analysis type

- $\quad$ Container size and type

- $\quad$ Sample preservation.

\section{A-5.1.3 Field Logbooks}

In accordance with the Administrative Records and Document Control format, field logbooks will be used to record information necessary to interpret the analytical data. All field logbooks will be controlled and managed according to Management Control Procedure (MCP)-1194, "Logbook Practices 
for ER and D\&D\&D Projects." Field logbooks will include the sample logbooks, the Field Team Leader's logbook, and field instrument calibration/standardization logbook.

A.5.1.3.1 Sample Logbooks. Generally, the field team will use the field team leader logbook to record pertinent information. Each logbook entry will contain information such as physical measurements (if applicable), all QC samples, and shipping information (e.g., collection dates, shipping dates, cooler ID number, destination, chain of custody number, name of shipper).

A.5.1.3.2 Field Team Leader's Daily Logbook. A project logbook maintained by the Field Team Leader will contain a daily summary of team activities, problems encountered, visitor log, and list of site contacts. This logbook will be signed and dated at the end of each day's sampling activities.

A.5.1.3.3 Field Instrument Calibration/Standardization Logbook. A logbook containing records of calibration data will be maintained for each piece of equipment requiring periodic calibration or standardization. This logbook will contain sheets to record the date, time, method of calibration, and instrument ID number.

\section{A-5.2 Sampling Handling}

Analytical samples for laboratory analyses will be collected in precleaned containers and packaged according to recommended procedures by the American Society for Testing and Materials (ASTM) or the Environmental Protection Agency (EPA). The QA samples will be included to satisfy QA requirements for the field operation as outlined in the QAPjP (DOE-ID 2003b). Only qualified analytical and testing laboratories will analyze these samples.

\section{A-5.2.1 Sample Preservation}

Preservation of water samples will be performed immediately upon sample collection. If required for preservation, acid may be added to the bottles prior to sampling. The temperature will be checked periodically prior to shipment to certify adequacy for those samples requiring temperatures at $4^{\circ} \mathrm{C}\left(39^{\circ} \mathrm{F}\right)$ for preservation. Ice chests (coolers) containing frozen, reusable ice will be used to chill samples, if required, in the field after sample collection.

\section{A-5.2.2 Chain-of-Custody Procedures}

The chain-of-custody procedures will be followed per MCP-3480 and PRD-5030, "Environmental Instructions for Facilities, Processes, Materials, and Equipment," and the QAPjP. Sample bottles will be stored in a secured area accessible only to the field team members.

\section{A-5.2.3 Sample Transportation}

Samples will be shipped in accordance with the regulations issued by the U.S. Department of Transportation (DOT) (49 Code of Federal Regulations [CFR] Parts 171 through 179) and EPA sample handling, packaging, and shipping methods (40 CFR 262 Subpart C, "Pre-Transport Requirements," and 40 CFR 263, "Standards Applicable to Transporters of Hazardous Waste"). All samples will be packaged in accordance with the requirements set forth in MCP-3480 and PRD-5030. 


\section{A-5.2.4 Custody Seals}

Custody seals will be placed on all shipping containers in such a way as to ensure that sample integrity is not compromised by tampering or unauthorized opening. Clear plastic tape will be placed over the seals to ensure that the seals are not damaged during shipment.

\section{A-5.2.5 On-Site and Off-Site Shipping}

An on-Site shipment is any transfer of material within the perimeter of the INEEL. Site-specific requirements for transporting samples within Site boundaries and those required by the shipping/receiving department will be followed. Shipment within the INEEL boundaries will conform to DOT requirements, as stated in 49 CFR, "Transportation." Off-Site sample shipments will be coordinated with INEEL Packaging and Transportation personnel as necessary, and will conform to all applicable DOT requirements.

\section{A-5.3 Document Revision Requests}

Revisions to this document will follow the requirements set forth in MCP-233, "Process for Developing, Releasing, and Distributing ER Documents." 


\section{A-6 DATA MANAGEMENT}

Data will be controlled and managed in accordance with the Data Management Plan for the Idaho National Engineering Laboratory Environmental Restoration Program (INEEL 1995).

\section{A-6.1 Analytical Data}

Table 4 of the O\&M Plan lists the requirements for the data generated in the various sampling events for the Operable Unit 1-07B activities. All definitive analytical data generated for performance monitoring are reported directly to the SMO for verification and validation per the requirements of this section or the appropriate sampling and analysis plan or field sampling plan.

The SMO enters the analytical results and QC data in the Integrated Environmental Data Management System and provides the remedial design/remedial action project manager with a limitations and validation report for data validated to Level A or B criteria, as defined in Guide-7003, "Levels of Analytical Method Data Validation," or results tables for data validated to Level C. 


\section{A-7 REFERENCES}

40 CFR 262, Subpart C, 2002, "Pre-Transport Requirements," Code of Federal Regulations, Office of the Federal Register, February 2002.

40 CFR 263, 2002, "Standards Applicable to Transporters of Hazardous Waste," Code of Federal Regulations, Office of the Federal Register, February 2002.

40 CFR 171, 2003, "General Information, Regulations and Definitions," Code of Federal Regulations, Office of the Federal Register, September 2003.

49 CFR, 2003, "Transportation," Code of Federal Regulations, Office of the Federal Register, September 2003.

49 CFR 172, 2003, "Hazardous Material Table, Special Provisions, Hazardous Materials Communications, Emergency Response Information, and Training Requirements," Code of Federal Regulations, Office of the Federal Register, September 2003.

49 CFR 173, 2003, "Shippers-General Requirements for Shipments and Packagings," Code of Federal Regulations, Office of the Federal Register, August 2003.

49 CFR 174, 2003, "Carriage by Rail," Code of Federal Regulations, Office of the Federal Register, August 2003.

49 CFR 175, 2003, "Carriage by Aircraft," Code of Federal Regulations, Office of the Federal Register, July 2003.

49 CFR 176, 2003, "Carriage by Vessel," Code of Federal Regulations, Office of the Federal Register, July 2003.

49 CFR 177, 2003, "Carriage by Public Highway," Code of Federal Regulations, Office of the Federal Register, August 2003.

49 CFR 178, 2003, "Specifications for Packagings," Code of Federal Regulations, Office of the Federal Register, September 2003.

49 CFR 179, 2003, "Specifications for Tank Cars," Code of Federal Regulations, Office of the Federal Register, August 2003.

DOE-ID, 2003a, New Pump and Treat Facility Operations and Maintenance Plan for Test Area North Final Groundwater Remediation, Operable Unit 1-07B, DOE/ID-99-10684, Revision 3,

U.S. Department of Energy Idaho Operations Office, September 2003.

DOE-ID, 2003b, Quality Assurance Project Plan fort the Waste Area Groups 1, 2, 3, 4, 5, 6, 7, 10, and Inactive Sites, DOE/ID-10587, Revision 7, U.S. Department of Energy Idaho Operations Office, September 2002.

GDE-7003, 2002, "Levels of Analytical Method Data Validation," Revision 1, December 2002. 
INEEL, 1995, Data Management Plan for the Idaho National Engineering Laboratory Environmental Restoration Program, INEL-95/0257, Revision 1, Idaho National Engineering and Environmental Laboratory, June 1995.

MCP-233, 2002, "Process for Developing, Releasing, and Distributing ER Documents (Supplemental to MCP-135 and MCP-9395)," Revision 4, Environmental Restoration Work Processes Manual, June 2002.

MCP-3480, 2002, "Environmental Instructions for Facilities, Processes, Materials, and Equipment," Revision 8, Manual 8-Environmental Protection and Compliance, November 2002.

MCP-1 194, 2003, "Logbook Practices for ER and D\&D\&D Projects," Revision 1, Environmental Restoration Work Processes Manual, May 003.

PRD-5030, 2002, "Environmental Instructions for Facilities, Processes, Materials, and Equipment," Revision 8, Manual 8-Environmental Protection and Compliance, April 2002. 


\section{Appendix B NPTF Prefinal Inspection Checklist}


B-2 

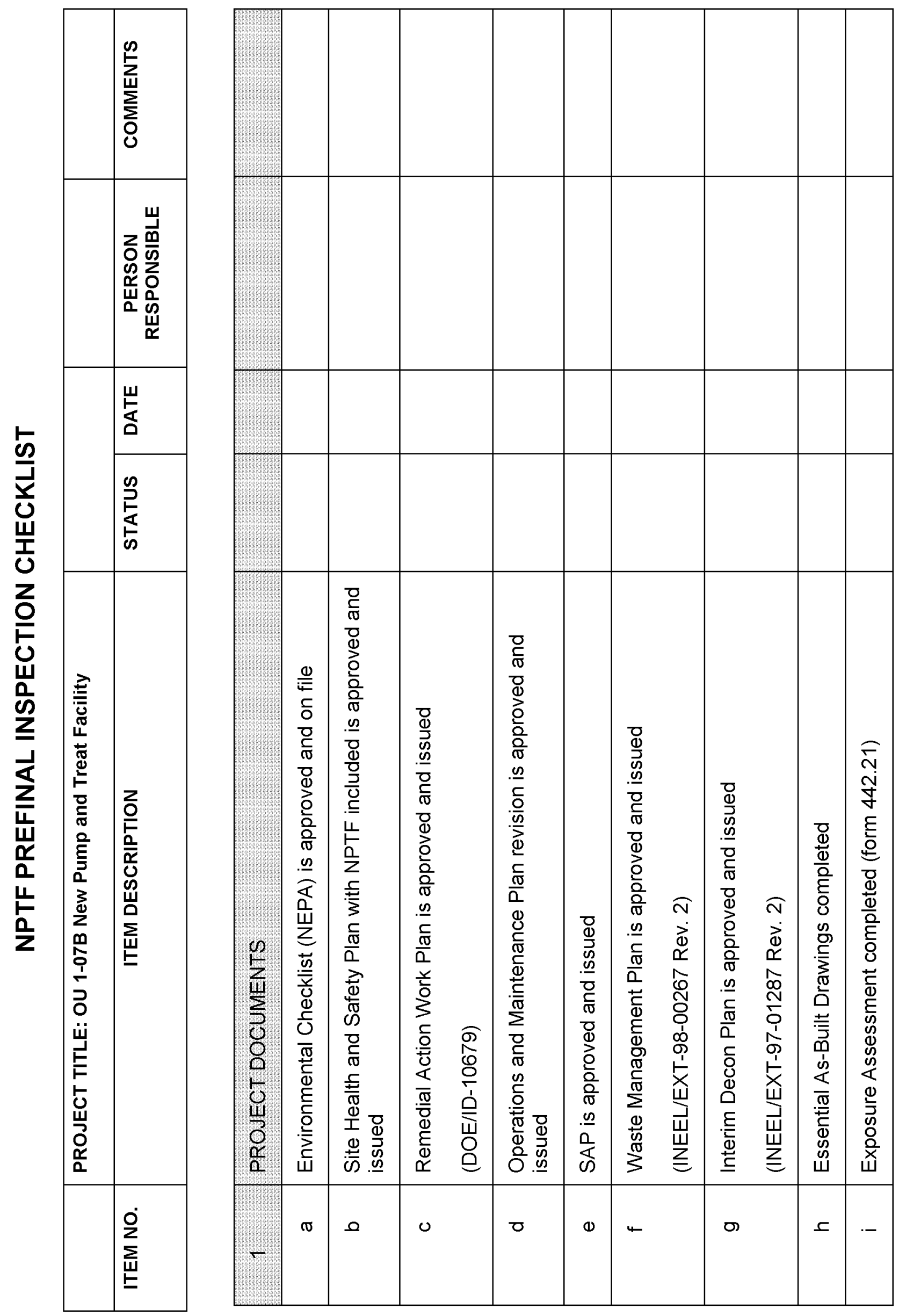

B-3 

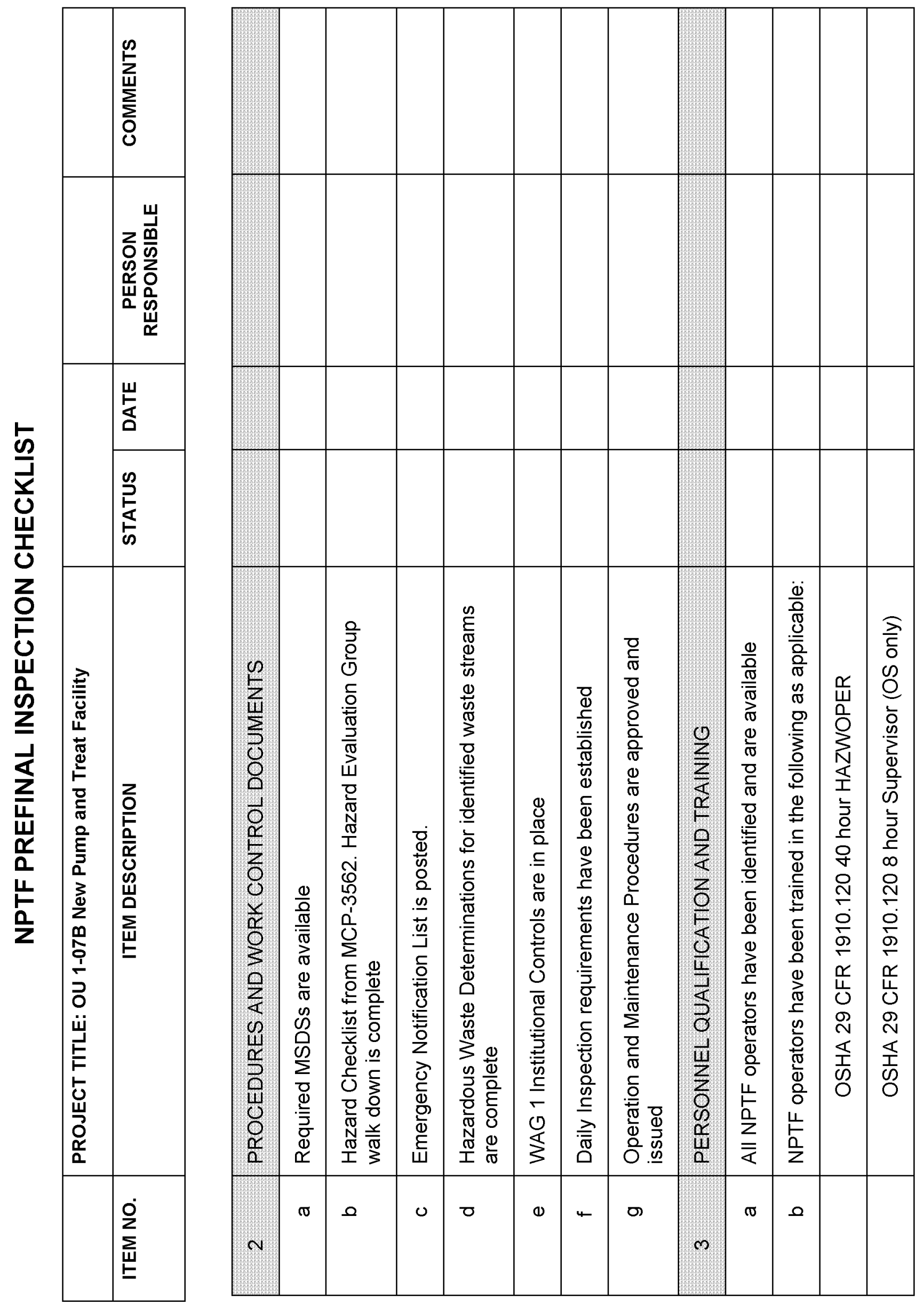

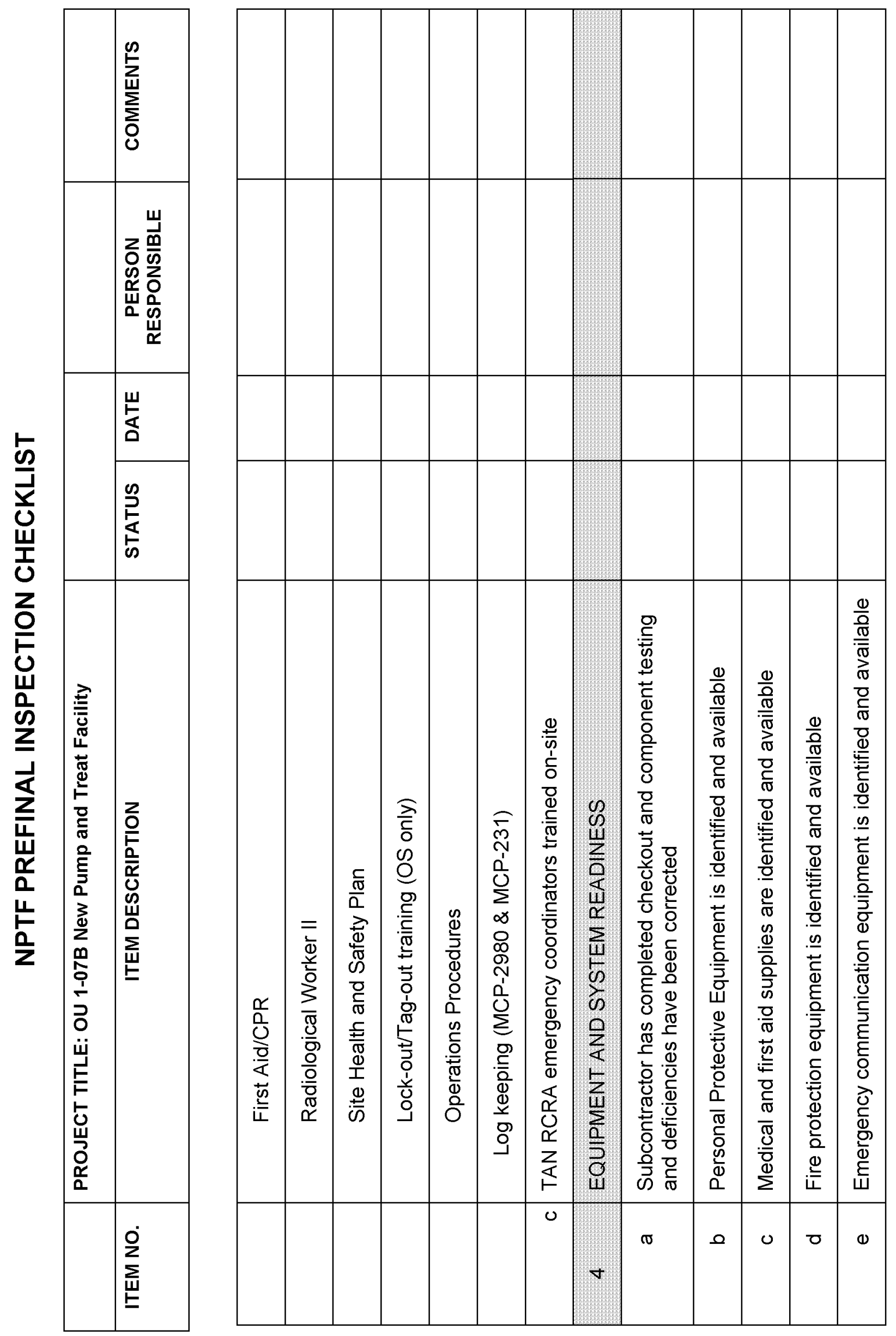

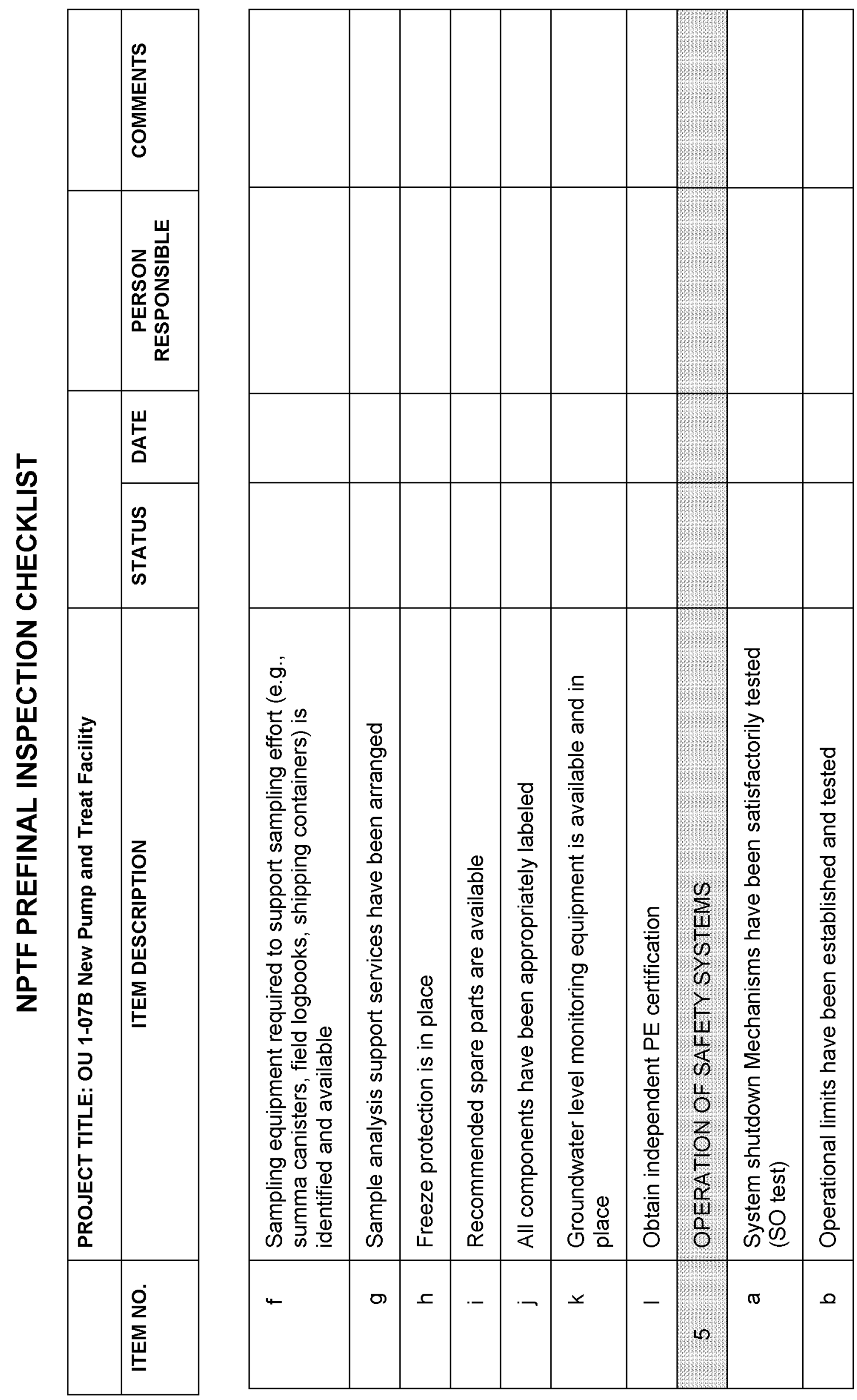

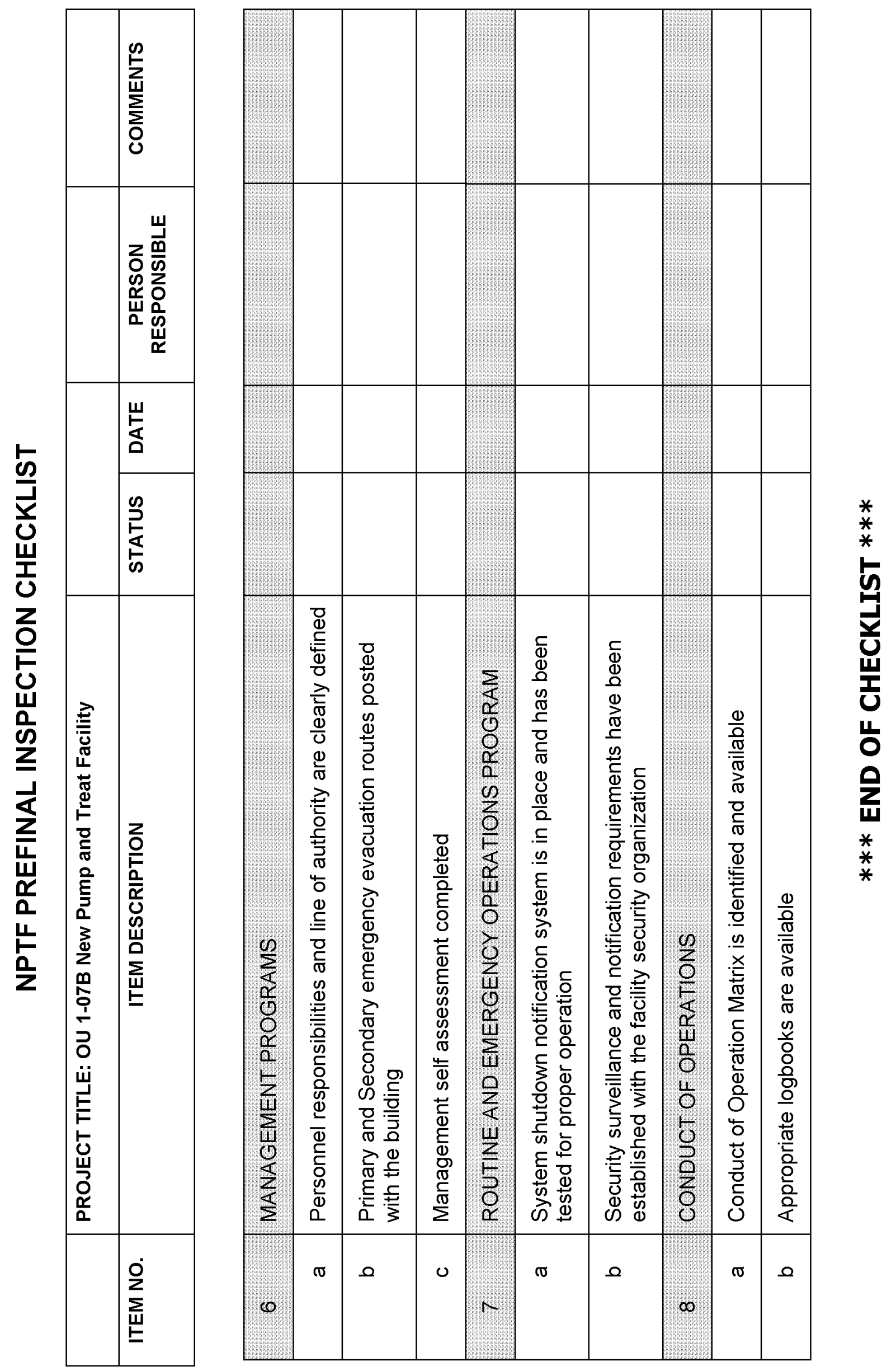

B-7 
Appendix C

NPTF Effluent Cumulative Risk Calculation 


$$
\text { C-2 }
$$




\section{Appendix C \\ NPTF Effluent Cumulative Risk Calculation}

The following information describes the methods and assumptions used to calculate the Carcinogenic Cumulative Risk for the effluent water being discharged from the New Pump and Treat Facility (NPTF). The calculation will be used to determine compliance with the requirements established in the No-Longer-Contained-In Determination (NLCID) ${ }^{1}{ }^{1}$ specific to the NPTF effluent water as agreed to with the State of Idaho Department of Environmental Quality.

The basis for this calculation comes from the EPA Region 9 development of their overall Preliminary Remediation Goals (PRG) Table. This PRG table was developed based on risk data and calculations established by EPA guidance and published databases.

An Excel spreadsheet is used to calculate the NPTF effluent cumulative risk. This spreadsheet uses the EPA Region 9 PRG information for the contaminants that are applicable to the NPTF effluent.

Assumptions used in developing the spreadsheet and the Region 9 PRG's are as follows:

- A family of four uses $720 \mathrm{~L}$ of water per day

- A Typical Dwelling Volume is $150,000 \mathrm{~L}$

- $\quad$ Air exchange rate of 0.25 airchanges $/ \mathrm{hr}$

- Water to Air Transfer Efficiency of 50\% (1/2 concentration of chemical in water will be transferred to the air

- $\quad$ Pathways include Ingestion and Inhalation only

- Methods of contaminant volatilization include showering, laundry, and dishwashing.

The NLCID requires a carcinogenic cumulative risk calculation based on Volatile Organic Compounds (VOC). Therefore, the calculation includes the EPA Region 9 contaminant data for all chemicals that are designated as a carcinogen and as a VOC (has a Henry's Law Constant greater than $1 \mathrm{x}$ $10^{-5}$ and a Molecular Weight less than $200 \mathrm{~g} / \mathrm{mole}$ ).

The PRG equation used to calculate the individual risk for each contaminant is as shown in Equation (A-1). The values used and reference to the data source are also listed.

The values used for $\mathrm{CSF}_{\circ}$ and $\mathrm{CSF}_{\mathrm{i}}$ are shown in the Excel spreadsheet and were obtained from either the IRIS or HEAST databases. An indicator is included that identifies which data source was used for each contaminant. The values that are used were obtained from the November 2000 Region 9 PRG Tables. For some contaminants, a value is not currently available in the EPA databases. In these cases, the value used is either a value derived from an EPA route extrapolation method (these data are indicated with an "r") or, is a provisional value prepared by the National Center for Environmental Assessment

1. Letter from Brian Monson, DEQ to Dave Wessman, DOE-ID, dated February 5, 2001. ID No. ID4890008952 
(NCEA) Superfund Technical Support Center in response to a specific request from Region 9 (these data are indicated with an " $n$ "). All the values will be reviewed periodically (during the 5 year reviews) to check for, and update, the risk values used in the spreadsheet to include any revised or new values.

$$
P R G(u g / l)=\frac{\left[T R x A T_{c} x 1000 u g / m g\right]}{E F_{r}\left[\left(I F W_{a d j} x C S F_{o}\right)+\left(V F_{w} x \operatorname{Inh} F_{a d j} x C S F_{i}\right)\right]}
$$

Where:

\begin{tabular}{|c|c|c|}
\hline & Value & Reference \\
\hline$T R=$ Target Cancer Risk & $1 \mathrm{E}-06$ & \\
\hline$A T_{c}=$ Average Time - Carcinogens (days) & 25550 & $\begin{array}{l}\text { RAGS (Part A), EPA } 1989 \\
\text { (EPA/540/01-89/002) }\end{array}$ \\
\hline$E F_{r}=$ Exposure Frequency - residential $(\mathrm{d} / \mathrm{y})$ & 350 & $\begin{array}{l}\text { Exposure Factors, EPA 1991 } \\
\text { (OSWER No. 9285.6-6-03) }\end{array}$ \\
\hline$I F W_{a d j}=$ Ingestion Factor, water $([\mathrm{L}-\mathrm{yr}] /[\mathrm{kg}-\mathrm{d}])$ & 1.1 & $\begin{array}{l}\text { By analogy to RAGS (Part B) } \\
\text { Region } 9\end{array}$ \\
\hline$C S F_{o}=$ Cancer Slope Factor oral $(\mathrm{mg} / \mathrm{kg}-\mathrm{d})^{-1}$ & & IRIS, HEAST, or NCEA \\
\hline$V F_{w}=$ Volatilization factor for water $(\mathrm{L} / \mathrm{m} 3)$ & 0.5 & $\begin{array}{l}\text { RAGS(Part B), EPA } 1991 \\
\text { (OSWER No. 9285.7-01B) }\end{array}$ \\
\hline $\operatorname{Inh} F_{a d j}=$ Inhalation Factor $\left(\left[\mathrm{m}^{3}-\mathrm{yr}\right] /[\mathrm{kg}-\mathrm{d}]\right)$ & 11 & $\begin{array}{l}\text { By analogy to RAGS (Part B) } \\
\text { Region } 9\end{array}$ \\
\hline$C S F_{i}=$ Cancer Slope Factor inhaled $(\mathrm{mg} / \mathrm{kg}-\mathrm{d})^{-1}$ & & IRIS, HEAST, or NCEA \\
\hline
\end{tabular}

Individual contaminant risk values are calculated by dividing the measured contaminant concentration by the PRG (in $u g / l$ ). The table then displays the total risk associated with the particular contaminant. The individual risk values for each contaminant are then summed together to provide the cumulative risk value. Figure C-1 represents the excel spreadsheet that will be used to perform the NPTF cumulative risk calculation.

The sample analysis methods used for the NPTF VOC compliance samples primarily have a Method Detection Limit (MDL) of $2 \mathrm{ug} / \mathrm{l}$. The one exception is the analytical method used for vinyl chloride, which has an MDL of $1 \mathrm{ug} /$. By using this method, results can be reported below the MCL for vinyl chloride, which is $2 \mathrm{ug} / \mathrm{l}$. Only contaminants with analytical values that are above the applicable MDL will be included in the cumulative risk calculation.

It should be noted that for vinyl chloride, the concentration that corresponds to a $1 \times 10^{-5}$ risk value is approximately $0.4 \mathrm{ug} / \mathrm{l}$. This value is less than the applicable MDL. Instead of changing the analytical method used for vinyl chloride to one that has a much lower MDL, process knowledge regarding the air stripper removal efficiency for vinyl chloride will be used. The removal efficiency of vinyl chloride through the air stripper is $99.99 \%$. In order to get an effluent concentration of vinyl chloride above 
$0.4 \mathrm{ug} / \mathrm{l}$, the influent water concentration for vinyl chloride would have to be greater than $4,000 \mathrm{ug} / \mathrm{l}$. An influent concentration of vinyl chloride at this concentration is highly unlikely and would have to be generated from some mechanism (i.e., in situ bioremediation) that is currently not present in the surrounding subsurface. The influent water will be monitored monthly to check for any generation of vinyl chloride in the extracted groundwater. To ensure that vinyl chloride does not pose an unacceptable risk, an administrative control will be used to monitor the influent water for vinyl chloride. If the influent concentration of vinyl chloride ever exceeds $100 \mathrm{ug} /$, then the sample analysis method used to evaluate the concentration of vinyl chloride in the effluent water will be changed to use a method with an MDL of less than $0.2 \mathrm{ug} /$.

Results of the sampling analysis and the associated cumulative risk calculation will be provided in the NPTF Operation Reports. 


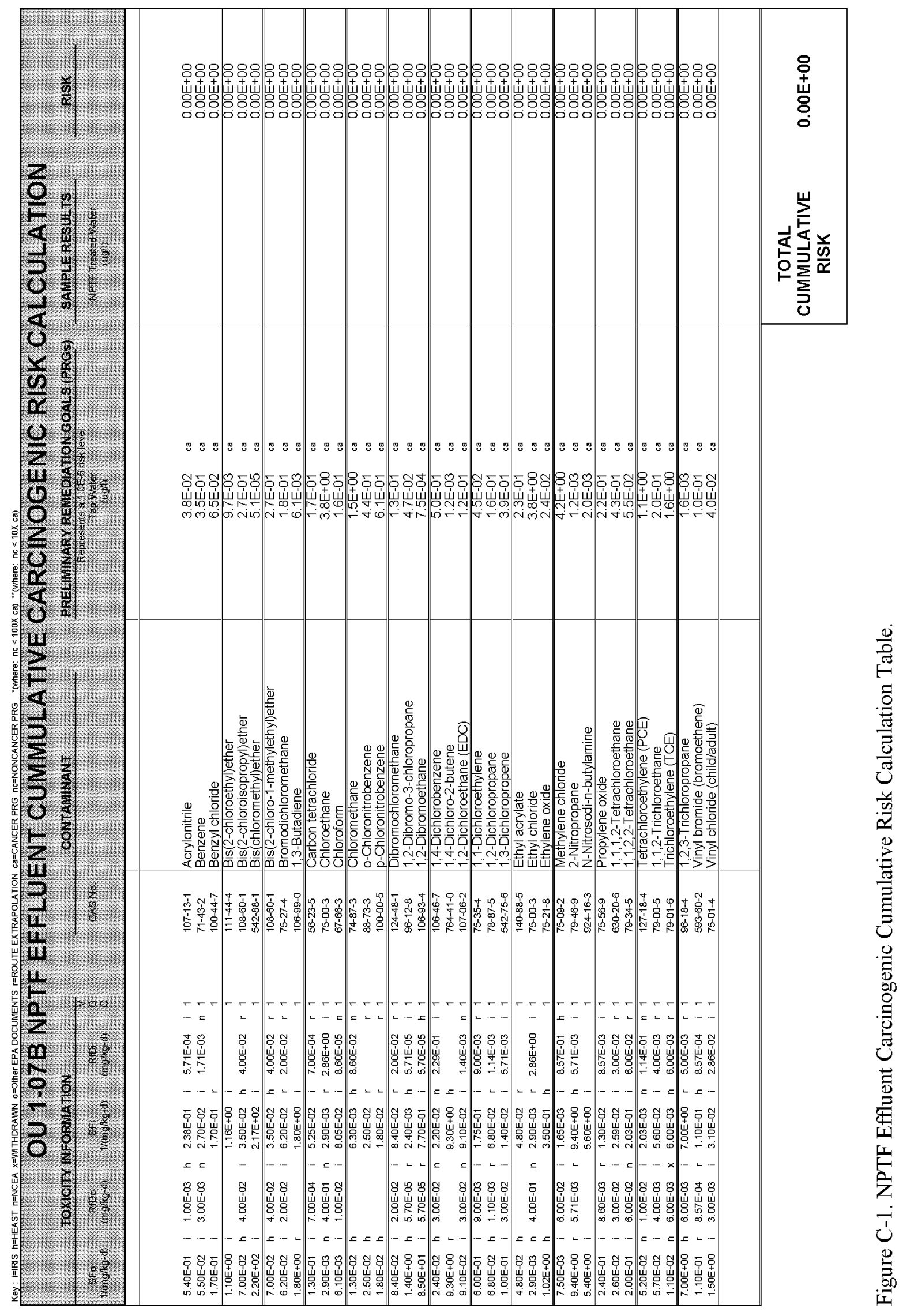

